\title{
Impact of the Asian monsoon on the extratropical lower stratosphere: trace gas observations during TACTS over Europe 2012
}

\author{
Stefan Müller ${ }^{1}$, Peter Hoor ${ }^{1}$, Heiko Bozem ${ }^{1}$, Ellen Gute ${ }^{2, a}$, Bärbel Vogel ${ }^{3}$, Andreas Zahn ${ }^{4}$, Harald Bönisch ${ }^{5}$, \\ Timo Keber ${ }^{5}$, Martina Krämer ${ }^{3}$, Christian Rolf ${ }^{3}$, Martin Riese ${ }^{3}$, Hans Schlager ${ }^{6}$, and Andreas Engel ${ }^{5}$ \\ ${ }^{1}$ Institute for Atmospheric Physics, Johannes Gutenberg University, Mainz, Germany \\ ${ }^{2}$ Department of Atmospheric Chemistry, Max Planck Institute for Chemistry, Mainz, Germany \\ ${ }^{3}$ Institute for Energy and Climate Research, Stratosphere (IEK-7), Forschungszentrum Jülich, Jülich, Germany \\ ${ }^{4}$ Institute of Meteorology and Climate Research (IMK), Karlsruhe Institute of Technology (KIT), Karlsruhe, Germany \\ ${ }^{5}$ Institute for Atmospheric and Environmental Sciences, Goethe University Frankfurt, Frankfurt am Main, Germany \\ ${ }^{6}$ Institute for Atmospheric Physics, German Aerospace Research Center (DLR), Oberpfaffenhofen, Germany \\ ${ }^{a}$ now at: Department of Chemistry, University of Toronto, Toronto, Canada
}

Correspondence to: Stefan Müller (stefan.mueller@uni-mainz.de)

Received: 22 September 2015 - Published in Atmos. Chem. Phys. Discuss.: 10 December 2015

Revised: 20 June 2016 - Accepted: 12 July 2016 - Published: 25 August 2016

\begin{abstract}
The transport of air masses originating from the Asian monsoon anticyclone into the extratropical upper troposphere and lower stratosphere (Ex-UTLS) above potential temperatures $\Theta=380 \mathrm{~K}$ was identified during the HALO aircraft mission TACTS in August and September 2012. In situ measurements of $\mathrm{CO}, \mathrm{O}_{3}$ and $\mathrm{N}_{2} \mathrm{O}$ during TACTS flight 2 on 30 August 2012 show the irreversible mixing of aged stratospheric air masses with younger (recently transported from the troposphere) ones within the Ex-UTLS. Backward trajectories calculated with the trajectory module of CLaMS indicate that these tropospherically affected air masses originate from the Asian monsoon anticyclone. These air masses are subsequently transported above potential temperatures $\Theta=380 \mathrm{~K}$ from the monsoon circulation region into the ExUTLS, where they subsequently mix with stratospheric air masses. The overall trace gas distribution measured during TACTS shows that this transport pathway had affected the chemical composition of the Ex-UTLS during boreal summer and autumn 2012. This leads to an intensification of the tropospheric influence on the extratropical lower stratosphere with $\mathrm{PV}>8$ pvu within 3 weeks during the TACTS mission. During the same time period a weakening of the tropospheric influence on the lowermost stratosphere (LMS) is determined. The study shows that the transport of air masses
\end{abstract}

originating from the Asian summer monsoon region within the lower stratosphere affects the change in the chemical composition of the Ex-UTLS over Europe and thus contributes to the flushing of the LMS during summer 2012.

\section{Introduction}

The UTLS region (Fig. 1) encompasses the global tropopause region and the lower part of the stratosphere up to potential temperature levels of $\Theta=430 \mathrm{~K}$, which coincides with the lower end of the tropical pipe in the stratosphere (e.g. Hegglin and Shepherd, 2009; Palazzi et al., 2009). Transport in the UTLS is thus affected by the stratospheric Brewer-Dobson circulation (BDC; Brewer, 1949; Dobson, 1956) with slow diabatic ascent in the tropics across the tropical tropopause layer (TTL; Fueglistaler et al., 2009) and diabatic downwelling in the extratropical stratosphere. The BDC consists of two major different transport pathways. The deep branch of the BDC transports air from the tropics to the extratropics via the upper stratosphere and lower mesosphere on timescales of several years (Butchart, 2014). In contrast, the shallow branch of the BDC mainly affects the region between $\Theta=380$ and $430 \mathrm{~K}$ by quasi-isentropic transport 
and mixing (Hegglin and Shepherd, 2007; Spackman et al., 2007; James and Legras, 2009; Birner and Bönisch, 2011). On the basis of in situ data, Volk et al. (1996) and Flocke et al. (1999) quantified entrainment rates for the tropical stratosphere, highlighting the importance of mixing above $\Theta=380 \mathrm{~K}$ for the ascending part of the BDC. In the extratropics below $\Theta=380 \mathrm{~K}$ the lowermost stratosphere (LMS; Hoskins et al., 1985) as part of the extratropical UTLS (ExUTLS in the following) is affected by rapid isentropic transport and mixing across the subtropical jet. Transport across the extratropical tropopause layer (ExTL) further potentially contributes to the composition of the lower part of the ExUTLS. The ExTL and LMS are mainly characterised by exchange processes across the tropopause on timescales of days to weeks (Berthet et al., 2007; Bönisch et al., 2009; Hoor et al., 2010; Konopka and Pan, 2012; Jurkat et al., 2014). A detailed knowledge of the relative strength of these transport pathways is of major importance to quantify the chemical composition of the Ex-UTLS, which in turn determines the radiative, dynamical and chemical impact of this atmospheric region on the climate system (Forster and Shine, 2002; Riese et al., 2012).

As shown in Bönisch et al. (2009) and Ploeger et al. (2013) the seasonality of stratospheric transport processes above $\Theta=380 \mathrm{~K}$ leads to a seasonality of the chemical composition up to $\Theta=430 \mathrm{~K}$ (the bottom of the tropical pipe) and a "flushing" of the lower stratosphere with young tropical air masses up to this level in summer and autumn (Hegglin and Shepherd, 2007). In this context, the Asian summer monsoon is an important pathway for the transport of tropospheric constituents into the stratosphere and has gained increasing attention in atmospheric research (Randel and Park, 2006; Randel et al., 2010; Park et al., 2007, 2008, 2009; Bergman et al., 2013; Fadnavis et al., 2013, 2014, 2015). The Asian summer monsoon consists of a cyclonic flow and convergence in the lower troposphere and a large-scale anticyclonic circulation in the upper troposphere between June and September centred over southern Asia (Randel et al., 2010). This circulation pattern is coupled with persistent deep convection (Bourassa et al., 2012; Bergman et al., 2013) which lifts chemical constituents from the lower troposphere to the tropopause region and lower stratosphere (Randel et al., 2010). Therefore, water vapour and tropospheric trace gases such as carbon monoxide (CO) and methane $\left(\mathrm{CH}_{4}\right)$ are relatively high within the Asian monsoon anticyclone (Rosenlof et al., 1997; Park et al., 2004, 2007), whereas ozone $\left(\mathrm{O}_{3}\right)$ is relatively low (Park et al., 2008). The air within the Asian monsoon anticyclone is strongly affected by anthropogenic pollution, which originates from the densely populated regions in South and Southeast Asia. During summer these pollutants accumulate in the anticyclone (Schuck et al., 2010; Baker et al., 2011; Richter et al., 2005) and strongly perturb the chemical composition of the monsoon tropopause region (Glatthor et al., 2009).

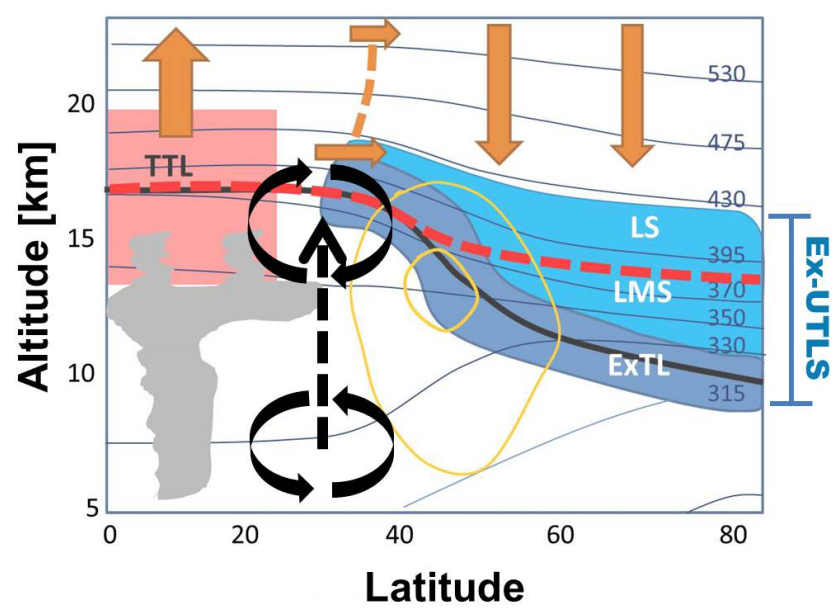

Figure 1. Illustration of the dynamical structure of the UTLS for the northern hemispheric summer adapted from Fig. 2b of Gettelman et al. (2011) and Fig. 9 of Riese et al. (2014). The thick black line denotes the location of the thermal tropopause. Thin solid lines denote isentropes, and the red dashed line highlights the $380 \mathrm{~K}$ isentrope. The location of the TTL is represented in light red. The ExUTLS is divided into the extratropical tropopause layer (ExTL) in dark blue and the lowermost (LMS) and lower stratosphere (LS) in light blue. The LMS and LS are separated by the $380 \mathrm{~K}$ isentrope. Yellow lines indicate the location of the jet stream. Orange arrows sketch the upward transport of air masses within the TTL and descending air masses in the extratropical stratosphere. Both regions are linked by the deep (upper horizontal arrow) and shallow (lower horizontal arrow) branch within the stratosphere. The stratospheric residual circulation as a part of the Brewer-Dobson circulation (BDC) can be subdivided into a deep and shallow branch (orange arrows). The location of the Asian monsoon circulation is schematically shown in black.

Since the monsoon tropopause is relatively high (Highwood and Hoskins, 1998), exchange processes between the troposphere and stratosphere in the region of the Asian monsoon may transport tropospheric constituents into the lower stratosphere to altitudes of up to $20 \mathrm{~km}$ (Park et al., 2008). The pathway and strength of troposphere-to-stratospheretransport (TST) in the tropopause region of the Asian monsoon are neither adequately understood nor quantified. In this context, the direct convective injection into the lower stratosphere (Rosenlof et al., 1997; Chen et al., 2012) and the separation of small anticyclones from the main anticyclone, referred to as "eddy shedding", is of major importance (Hsu and Plumb, 2000; Popovic and Plumb, 2001; Garny and Randel, 2013). The latter process can transport tropospheric trace gases and pollutants to mid- and high latitudes, where they mix with extratropical stratospheric air masses (Vogel et al., 2014). The impact of the Asian monsoon on the chemical composition of the northern hemispheric lower stratosphere cannot be easily separated from the upward transport of tropospheric air masses into the stratosphere in the tropics, which is regarded as the primary pathway for air masses 
entering the stratosphere (Holton et al., 1995). In the tropical lower stratosphere these ascending air masses are uplifted by the BDC and zonally transported to higher latitudes by the shallow branch of the BDC.

In this paper we present in situ trace gas measurements of $\mathrm{CO}, \mathrm{N}_{2} \mathrm{O}$ (nitrous oxide), and $\mathrm{O}_{3}$ in the northern hemispheric extratropical stratosphere up to potential temperatures $\Theta=410 \mathrm{~K}$ obtained during the TACTS (Transport and Composition in the Upper Troposphere and Lower Stratosphere) aircraft campaign. The measurements are combined with analysis data of the European Centre for MediumRange Weather Forecast (ECMWF) and backward trajectories calculated with the trajectory module of the Chemical Lagrangian Model of the Stratosphere (CLaMS; McKenna et al., 2002a, b; Konopka et al., 2010; Pommrich et al., 2014).

We will focus on the impact of tropospheric air from the monsoon region on the composition of the lower stratosphere on different timescales. "Young stratospheric" in this context denotes air masses which are clearly located in the stratosphere from a dynamical and chemical point of view but which still exhibit chemical signatures of previous tropospheric influence (e.g. $\mathrm{CO}$ mixing ratios larger than the $\mathrm{CO}$ equilibrium mixing ratio of chemically processed (aged) stratospheric air masses of $\mathrm{CO}=12.5 \pm 2.5 \mathrm{ppbv}$ ) (Herman et al., 1999; Flocke et al., 1999). Since the measurements were performed in boreal summer and autumn 2012 within a period of 4 weeks in a wide range of the northern hemispheric UTLS, the potential influence of the Asian monsoon on this transport pathway and therefore on the trace gas composition of the Ex-UTLS is studied. In the following we will use the term lower stratosphere (LS) when we refer to the stratospheric part of the Ex-UTLS. This refers to the lower stratosphere above the ExTL up to $\Theta=430 \mathrm{~K}$, which is different from the classical definition of the LMS.

The paper is organised as follows. Section 2 gives an overview of the measurements and methods applied. Section 3 presents a case study of TACTS flight 2 (30 August 2012), which illustrates the identification of irreversible mixing of young stratospheric air masses into the extratropical stratosphere above $\Theta=380 \mathrm{~K}$. Tracer-tracer scatter plots of TACTS flight 2 are analysed in Sect. 3.2. Section 3.3 shows the results of backward trajectory calculations, which indicate that transport and mixing from the Asian monsoon anticyclone into the Ex-UTLS cause the measured mixing event. In Sect. 4 we will provide strong evidence that the Asian summer monsoon strongly affected the mid-latitude lower stratosphere in summer 2012. A summary and discussion of the results are given in Sect. 5), followed by our conclusions in Sect. 6.

\section{Project overview, measurements, and backward trajectory calculation}

\subsection{The TACTS campaign 2012}

Our study is based on in situ measurements performed during the first atmospheric science missions with the new German research aircraft HALO in August/September 2012 TACTS and ESMVal (Earth System Model Validation). This paper focuses on eight research flights covering the Ex-UTLS between 15 and $70^{\circ} \mathrm{N}$ and $25^{\circ} \mathrm{W}$ and $15^{\circ} \mathrm{E}$ with typically 8 $10 \mathrm{~h}$ per flight (see Supplement).

The measurements of TACTS can be subdivided into two phases. The first phase with approximately 35 flights hours covered the time period between 30 August and 5 September 2012. The end phase was performed from 23 September until 26 September 2012. The flights, which are the basis for our study, were performed between 200 and $130 \mathrm{hPa}$ at up to $\Theta=410 \mathrm{~K}$. The composition change in the Ex-UTLS between both phases will be compared in Sect. 4. As shown in the Supplement, the flights were performed mainly in regions of horizontal potential vorticity (PV) gradients associated with Rossby wave activity. During both phases the flights covered a region from Cabo Verde to the Arctic. PV values exceeding $10 \mathrm{pvu}$ during both phases clearly indicate that stratospheric air masses were probed during TACTS.

\subsection{In situ trace gas measurements}

The study is mainly based on in situ data from the TRIHOP $\left(\mathrm{CO}\right.$ and $\left.\mathrm{N}_{2} \mathrm{O}\right)$ and FAIRO $\left(\mathrm{O}_{3}\right)$ instrument aboard HALO as described in the following subsections. Basic meteorological and aircraft data are taken from the Basic HALO Measurement and Sensor System (BAHAMAS). For the following analysis all data are merged to one dataset with a time resolution of $10 \mathrm{~s}(0.1 \mathrm{~Hz})$, corresponding to a horizontal resolution of $2.5 \mathrm{~km}$.

\subsubsection{TRIHOP in situ measurements of $\mathrm{CO}$ and $\mathrm{N}_{2} \mathrm{O}$}

The TRIHOP instrument is a three-channel quantum cascade laser infrared absorption spectrometer that measured $\mathrm{CO}$ and $\mathrm{N}_{2} \mathrm{O}$ during TACTS and ESMVal 2012 (Schiller et al., 2008). The instrument applies quantum cascade laser absorption spectroscopy (QCLAS) in the mid-infrared with a multipass absorption cell (type White), which is kept at a constant pressure of $P=30 \mathrm{hPa}$ and has a path length of $64 \mathrm{~m}$ and a volume of $2.7 \mathrm{~L}$. During TACTS/ESMVal the instrument was calibrated in situ approximately every 30 min during the flights against a secondary standard of compressed ambient air. The mixing ratios of the secondary standard were determined before and after the campaign in the laboratory against National Oceanic and Atmospheric Administration (NOAA) standards. The in-flight calibrations are used to identify and correct slow instrumental drifts in the post-flight data evaluation. The integration time for each species was $1.5 \mathrm{~s}$ at a duty 
cycle of $8 \mathrm{~s}$, which limits the temporal resolution of the measurements. During TACTS and ESMVal TRIHOP CO $\left(\mathrm{N}_{2} \mathrm{O}\right)$ data achieved a $2 \sigma$ precision of 1.0 (1.1) ppbv and a stability of the instrument of 1.5 (2.2) ppbv before applying the postflight data correction. Note that the stability is based on the mean drift between two subsequent calibrations, which were performed in intervals of $30 \mathrm{~min}$ during the flights. These instrumental drifts are corrected after the flights assuming linear drift, which leads to a reduced uncertainty. Hence, the total uncertainty relative to the working standard of 1.8 (2.5) ppbv can be regarded as an upper limit.

\subsubsection{FAIRO in situ measurements of $\mathrm{O}_{3}$}

FAIRO is a new accurate ozone instrument developed for use on board the HALO aircraft. It combines two techniques: UV photometry (light absorption of $\mathrm{O}_{3}$ at $\lambda=250-260 \mathrm{~nm}$ ) with high accuracy and chemiluminescence detection with high measurement frequency. A UV-LED is used as a light source for the UV photometer, which can be controlled well (in contrast to Hg lamps) for constant light emission. The $1 \sigma$ precision is $0.08 \mathrm{ppbv}$ at a measurement frequency of $4 \mathrm{~s}$ and a cuvette pressure of $1 \mathrm{bar}$, and the total uncertainty is $2 \%$. The chemiluminescence detector shows a measurement frequency of $12.5 \mathrm{~Hz}$ and a precision of $0.05 \mathrm{ppbv}$ (at $10 \mathrm{ppbv}$ absolute, a measurement frequency of $5 \mathrm{~Hz}$, and a pressure of $1 \mathrm{bar}$; Zahn et al., 2012).

\subsection{ECMWF (meteorological data)}

Global meteorological analysis data (T1279L91) of the ECMWF (European Centre for Medium-Range Weather Forecast) are used to interpret the meteorological situation during TACTS flight 2 as shown in Sect. 3.1. The meteorological fields are available every $3 \mathrm{~h}$ interpolated onto a regular grid of $0.5^{\circ}$ horizontal spacing (Dee et al., 2011).

\subsection{CLaMS-TRAJ (backward trajectories)}

The trajectory module of CLaMS (hereafter CLaMS-TRAJ) is used to calculate backward trajectories at the positions of the in situ observations (McKenna et al., 2002a, b; Konopka et al., 2010; Pommrich et al., 2014). The trajectories are initialised every $10 \mathrm{~s}$ along the flight paths and calculated 50 days back in time. For this purpose ERA-Interim reanalysis data (Dee et al., 2011) with a resolution of $1^{\circ}$ and 60 vertical levels from the surface up to $0.1 \mathrm{hPa}$ are interpolated in time and space on the starting point of the backward trajectories. Meteorological data, e.g. pressure, temperature, altitude, $\Theta$ and PV, are available every $1 \mathrm{~h}$ along the backward trajectories. The horizontal motion of the trajectories are driven by horizontal winds from the ERA-Interim reanalysis data. Diabatic heating rates are used to calculate vertical velocities in the UTLS region for pressure levels lower than $300 \mathrm{hPa}$ (Ploeger et al., 2010). Below $P>300 \mathrm{hPa}$ a pressure-based hybrid vertical coordinate is applied (Pommrich et al., 2014).
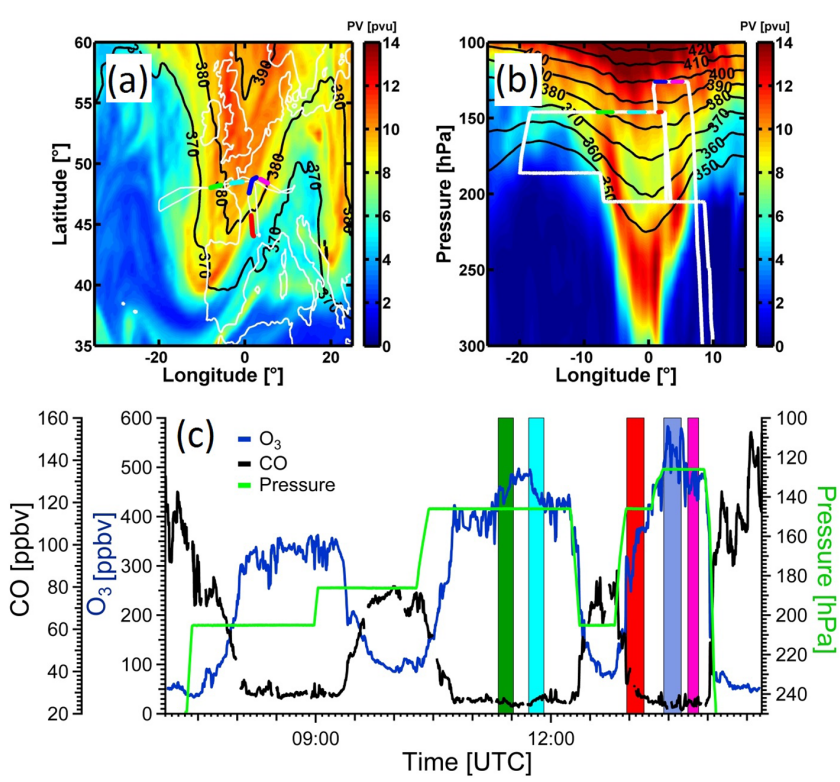

Figure 2. TACTS flight 2 on 30 August 2012. (a) ECMWF data (15:00 UTC) at $150 \mathrm{hPa}$ of potential vorticity (colour) and potential temperature (black contour lines). The thick white line is the flight path of TACTS flight 2. (b) Horizontal cross section of ECMWF potential vorticity data along $48.5^{\circ} \mathrm{N}$. Different colours in (a) and (b) indicate flight legs with measured mixing lines (see Sect. 3). (c) Time series of $\mathrm{CO}$ (black), $\mathrm{O}_{3}$ (blue) and pressure (green). Data points which form mixing lines are coloured according to panel (a) and (b). The total uncertainty of $\mathrm{CO}$ and $\mathrm{O}_{3}$ is mostly within the line thickness and therefore not shown (for individual error bars see Fig. 3 and Fig.4).

\section{Case study: TACTS flight 2 on 30 August 2012}

TACTS flight 2 on 30 August 2012 was performed over western Europe and the eastern Atlantic with take-off and landing in Oberpfaffenhofen near Munich (see Fig. 2). An eastwardpropagating trough over western Europe was crossed several times on pressure levels between 220 and $130 \mathrm{hPa}$, equivalent to flight altitudes between 11.5 and $15 \mathrm{~km}$. At the highest flight levels at 150 and $130 \mathrm{hPa}$, air masses with potential temperatures $\Theta$ between 380 and $410 \mathrm{~K}$ were sampled. PV derived from ECMWF data ranges between 8 and 14 pvu for these flight sections (Fig. 2a and b). Hence, these air masses are located above the dynamical tropopause, which is typically defined by PV values from 1 to 4 pvu in the extratropics (Hoskins et al., 1985; Randel et al., 2007). In the subtropics above $\Theta=340 \mathrm{~K}, \mathrm{PV}$ at the tropopause varies between 2 and 5 pvu (Kunz et al., 2011).

\subsection{Irreversible mixing within the stratosphere}

The time series of in situ $\mathrm{O}_{3}, \mathrm{CO}$ and pressure data for TACTS flight 2 are shown in Fig. 2c. The CO data indicates three sections with mixing ratios lower than $40 \mathrm{ppbv}$ during the flight, which is below $\mathrm{CO}$ mixing ratios in the northern 


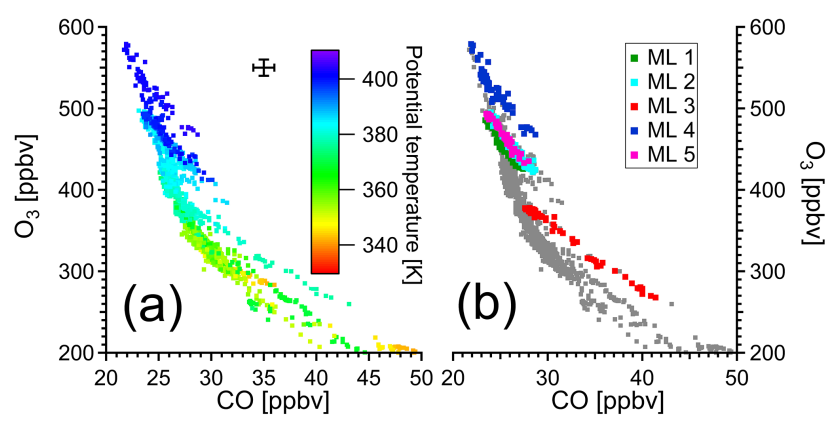

Figure 3. Stratospheric part of the $\mathrm{CO}-\mathrm{O}_{3}$ correlation for TACTS flight 2 on 30 August 2012. (a) Colour-coded with measured potential temperature. (b) Mixing lines (ML) in different colours in accordance with Fig. 2. Uncertainties in the $\mathrm{CO}$ and $\mathrm{O}_{3}$ data are shown separately as black crosses.

hemispheric free troposphere ranging from 50 to $130 \mathrm{ppbv}$ (Kumar et al., 2013). This indicates that the respective flight sections were within the stratosphere. Accompanying ozone values exceeding 200 ppbv (Strahan, 1999) and PV values larger than 5 pvu (see Fig. 2) support this conclusion.

During the last two flight segments from 10:30 until 12:15 and 13:00 until 14:00 UTC, stratospheric air masses with $\mathrm{CO}$ ranging from 20 to $30 \mathrm{ppbv}$ were sampled. These values are larger than the stratospheric equilibrium of $\mathrm{CO}=12.5 \pm 2.5 \mathrm{ppbv}$, which establishes as a result of $\mathrm{CO}$ production from methane and chemical degradation of $\mathrm{CO}$ on the timescale of several months (Flocke et al., 1999). Therefore, $\mathrm{CO}$ between 20 and $30 \mathrm{ppbv}$ indicates neither pure tropospheric nor completely $\mathrm{CO}$ degraded stratospheric air masses. Instead, such mixing ratios are the result of either irreversible mixing of tropospheric with stratospheric air or $\mathrm{CO}$ degradation of a former tropospheric air mass in the stratosphere (or a combination of both). In the following the correlation of $\mathrm{CO}$ with $\mathrm{O}_{3}$ during TACTS flight 2 is analysed to further examine the tropospheric influence in the ExUTLS for $\Theta$ between 380 and $410 \mathrm{~K}$.

Without any exchange between the troposphere and stratosphere, the $\mathrm{CO}-\mathrm{O}_{3}$ scatter plot would form an L shape (Fischer et al., 2000). Irreversible mixing of tropospheric (characterised by low $\mathrm{O}_{3}$ ) and stratospheric (characterised by low $\mathrm{CO}$ ) air masses appear as "mixing lines", which connect the mixed reservoirs on the tracer-tracer scatter plot (Hoor et al., 2002). Previous studies used the method of mixing lines to investigate exchange processes between the troposphere and stratosphere within the extratropical tropopause layer (ExTL; Zahn et al., 2000; Hoor et al., 2004; Pan, 2004). As shown in Fig. 3a the observations indicate irreversible mixing above $\Theta=380 \mathrm{~K}$. Since this is above the lowermost stratosphere isentropic cross tropopause, mixing is most likely not the driving mechanism for the observed mixing lines. Low $\mathrm{CO}$ and high $\mathrm{O}_{3}$ are accompanied by high values of $\Theta$. From the fact that all $\mathrm{CO}$ data points are well above the stratospheric equilibrium of $\mathrm{CO}=12.5 \pm 2.5 \mathrm{ppbv}$ (Herman et al., 1999; Flocke et al., 1999), tropospheric influence on timescales of weeks can be deduced for all probed air masses.

During TACTS flight 2, five mixing lines (ML) at potential temperatures $\Theta \geq 380 \mathrm{~K}$ can be identified. These are marked by individual colours in Fig. 3b. The respective colours in Fig. 2 mark the location of the measured mixing lines on the flight path (Fig. 2a and b) and along the time series of $\mathrm{CO}$ and $\mathrm{O}_{3}$ (Fig. 2c). ML 1, 2, 4 and 5 were encountered in the centre of the trough (Fig. 2a), while ML 3 is sampled at the trough edge further south. The five mixing lines correspond to individual flight sections along the flight track with durations of typically $15 \mathrm{~min}$ for each mixing line (see Fig. 2c). Table 1 lists the minimum and maximum values of $\mathrm{CO}, \mathrm{O}_{3}$ and $\Theta$ for each individual mixing line. Also shown are the number of data points, the flight distance, and $R^{2}$ from a linear fit regression for the respective mixing line. The applied fit is based on Press et al. (1992) and accounts for errors in both the $x$ and $y$ direction. The observed $\mathrm{CO}$ and $\mathrm{O}_{3}$ range (CO: $>4$ ppbv; $\mathrm{O}_{3}:>60 \mathrm{ppbv}$ ) of each mixing line is larger than the total measurement uncertainty of both species. Therefore, measurement artefacts causing these mixing lines can be excluded. $R^{2} \geq 0.89$ indicates that linearity for all mixing lines is justified. In general, ML 3 consists of higher $\mathrm{CO}$ and lower $\mathrm{O}_{3}$ mixing ratios and exhibits a larger difference between the minimum and maximum values of both species compared to ML 1, 2, 4 and 5. Significantly larger CO mixing ratios up to $40 \mathrm{ppbv}$ compared to $\mathrm{CO}<30 \mathrm{ppbv}$ for ML 1, 2, 4 and 5 in combination with a higher tropospheric end member (see Sect. 3.2) indicate shorter timescales for the transport and mixing of CO-rich air masses from the troposphere into the stratosphere for ML 3 compared to the other mixing events. The fact that ML 3 is measured at the trough edge and at lower potential temperatures compared to ML $1,2,4$ and 5 supports the assumption that different timescales are responsible for the formation of ML 3 and ML 1,2, 4 and 5. In the following section the origin of the $\mathrm{CO}$ enhanced air masses in the extratropical lower stratosphere is further investigated with $\mathrm{N}_{2} \mathrm{O}$ as an additional in situ-measured trace gas.

\subsection{Mixing line analysis}

This analysis seeks to determine the initial mixing ratios of the air parcels which lead to the formation of mixing lines (Hintsa et al., 1998; Hoor et al., 2002). This requires knowledge on the initial mixing ratio of one of the species involved. Since mixing ratios of trace gases like $\mathrm{O}_{3}$ and $\mathrm{N}_{2} \mathrm{O}$ at the tropopause are fairly constant compared to their stratospheric gradient, they can be used to as an initial estimate to analyse mixing across the tropopause. Nevertheless, mixing ratios just below the tropopause of trace gases like $\mathrm{O}_{3}$ and $\mathrm{N}_{2} \mathrm{O}$ are fairly constant compared to their stratospheric gradient. Thus, the determination of the so-called "tropospheric end member" is possible with the assumption of a constant tropospheric value for one of the constituents involved. This 
Table 1. Minimum and maximum values of potential temperature as well as $\mathrm{CO}$ and $\mathrm{O}_{3}$ mixing ratios for every mixing line. Additionally, the number of data points, the flight distance, and $R^{2}$ based on a linear regression are listed.

\begin{tabular}{lrrrrr}
\hline Mixing line & Line 1 & Line 2 & Line 3 & Line 4 & Line 5 \\
\hline$\Theta_{\min }[\mathrm{K}]$ & 381.5 & 385.3 & 377.0 & 399.0 & 396.5 \\
$\Theta_{\max }[\mathrm{K}]$ & 384.5 & 389.0 & 382.0 & 405.0 & 401.0 \\
\hline $\mathrm{CO}_{\min }[\mathrm{ppbv}]$ & 23.4 & 23.9 & 23.7 & 21.9 & 23.5 \\
$\mathrm{CO}_{\max }[\mathrm{ppbv}]$ & 27.4 & 28.7 & 41.4 & 28.7 & 28.0 \\
\hline $\mathrm{O}_{3}$ min $[\mathrm{ppbv}]$ & 425.59 & 421.75 & 248.27 & 467.82 & 433.01 \\
$\mathrm{O}_{3}$ max $[\mathrm{ppbv}]$ & 485.56 & 495.11 & 377.92 & 583.16 & 493.54 \\
\hline Data points & 71 & 71 & 60 & 65 & 51 \\
Flight distance [km] & 142 & 142 & 120 & 130 & 102 \\
$R^{2}$ & 0.96 & 0.96 & 0.99 & 0.89 & 0.96 \\
\hline
\end{tabular}
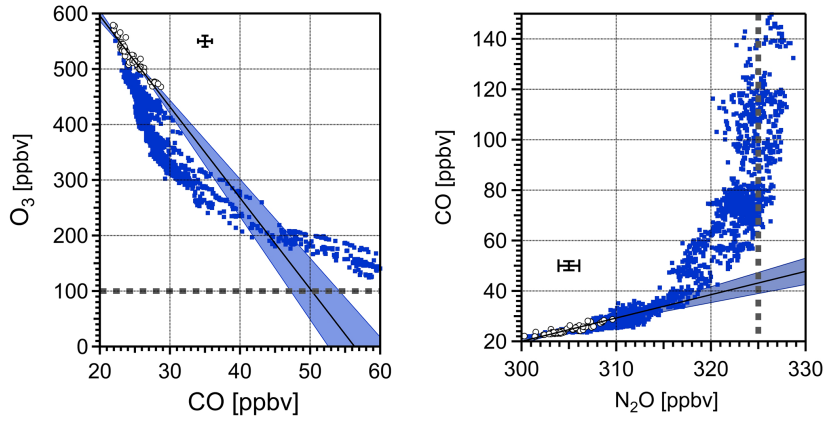

Figure 4. Linear fits for ML 4 based on the FITEXY routine described in Press et al. (1992). Blue dots: scatter plot of CO and $\mathrm{O}_{3}$ (left) as well as $\mathrm{N}_{2} \mathrm{O}$ and $\mathrm{CO}$ (right). Circles: individual data points forming the mixing line ML 4 . Solid black line: linear fit with confidence region (shaded area). Dotted lines indicate typical tropopause mixing ratios for $\mathrm{O}_{3}$ and $\mathrm{N}_{2} \mathrm{O}$ to determine the tropospheric mixing line "end member" $\left(R\left(\mathrm{O}_{3}\right)_{\text {Trop }}=100 \mathrm{ppbv}\right.$ (top) and $R\left(\mathrm{~N}_{2} \mathrm{O}\right)_{\text {Trop }}=25 \mathrm{ppbv}$ (bottom)). Uncertainties are separately shown as black crosses.

approach has been applied to ML 1-5 on the basis of the $\mathrm{CO}-\mathrm{O}_{3}$ and $\mathrm{N}_{2} \mathrm{O}-\mathrm{CO}$ scatter plot.

Figure 4 displays the tropospheric end member approximation for ML 4. The calculation of the shaded confidence region is based on the FITEXY approach described by Press et al. (1992), which accounts for uncertainties in the $x$ and $y$ direction. $\mathrm{O}_{3}$ at the tropopause varies between 60 and $120 \mathrm{ppbv}$, with a seasonal cycle and regional variations as well. For the end member approximation in this section a mixing ratio $\mathrm{O}_{3 \text { Trop }}=100 \mathrm{ppbv}$ is applied, which is a reasonable value for the northern hemispheric summer (Zahn and Brenninkmeijer, 2003; Thouret et al., 2006). Alternatively, $\mathrm{N}_{2} \mathrm{O}$ can be used to determine a tropospheric end member, since it is inert in the troposphere. It thus shows an almost homogeneous tropospheric distribution, which is a great advantage compared to any reactive tracer, for example $\mathrm{O}_{3}$. The sinks of $\mathrm{N}_{2} \mathrm{O}$ are entirely in the stratosphere, which leads to a weak gradient of $\mathrm{N}_{2} \mathrm{O}$ at the tropopause. Therefore, the $\mathrm{N}_{2} \mathrm{O}$ mixing ratio at the tropopause is well defined, which makes $\mathrm{N}_{2} \mathrm{O}$ an appropriate tracer for tropospheric air masses (Assonov et al., 2013; Müller et al., 2015). In August/September 2012 the free-tropospheric mixing ratio of $\mathrm{N}_{2} \mathrm{O}$ was $325 \pm 0.5 \mathrm{ppbv}$, which is applied as $\mathrm{N}_{2} \mathrm{O}_{\text {Trop }}$ (www.esrl.noaa.gov/gmd/hats/combined/N2O.html). Table 2 lists the potential range of the tropospheric end member of $\mathrm{CO}$ from the calculated confidence region (shaded area in Fig. 4) for $\mathrm{O}_{3}$ Trop $=100 \mathrm{ppbv}$ and $\mathrm{N}_{2} \mathrm{O}_{\text {Trop }}=325 \mathrm{ppbv}$, respectively. The results can be summarised as follows:

- The tropospheric end members of CO for ML 1, 2, 4 and 5 are in a range from 35 to $55 \mathrm{ppbv}$. This is at the lower limit and even below typical tropospheric $\mathrm{CO}$ mixing ratios.

- End members of $\mathrm{CO}$ based on the $\mathrm{CO}-\mathrm{O}_{3}$ correlation are different from the respective $\mathrm{N}_{2} \mathrm{O}-\mathrm{CO}$ end members.

- CO end members between 55 and 70 ppbv for ML 3 include typical mixing ratios at the tropopause, even though $\mathrm{CO}$ is at the lower limit for tropospheric $\mathrm{CO}$ mixing ratios.

A tropospheric $\mathrm{CO}$ end member lower than typical tropopause values indicates that the respective mixing line is not the result of mixing between pure tropospheric and stratospheric air masses. (The term "pure" is used in this context to describe undiluted and photochemically unprocessed tropospheric air masses.) For these mixing lines the tropospheric $\mathrm{CO}$ end members do not reflect the original $\mathrm{CO}$ mixing ratio of the unmixed air mass. $\mathrm{CO}$ end member values lower than the range of $\mathrm{CO}$ mixing ratios at the tropopause can only arise from the chemical degradation of $\mathrm{CO}$ in the stratosphere or previous mixing or a combination of both. Therefore, the observed mixing lines are the result of mixing between two stratospheric air masses with different age. 
Table 2. Tropospheric "end members" for every mixing line based on the tracer-tracer correlations of $\mathrm{O}_{3}$ and $\mathrm{CO}$ as well as $\mathrm{N}_{2} \mathrm{O}$ and $\mathrm{CO}$ (cf. Fig. 4). The values are based on the intercept between the calculated confidence regions with the assumed mixing ratio of $\mathrm{O}_{3}$ and $\mathrm{N}_{2} \mathrm{O}$ at the tropopause in Fig. 4.

\begin{tabular}{lccccc}
\hline Mixing line & Line 1 & Line 2 & Line 3 & Line 4 & Line 5 \\
\hline$R_{\text {Trop }}\left(\mathrm{O}_{3}\right)=100 \mathrm{ppbv}$ & & & & & \\
$\mathrm{CO}_{\min }[\mathrm{ppbv}]$ & 42.0 & 45.9 & 59.3 & 47.2 & 44.5 \\
$\mathrm{CO}_{\max }[\mathrm{ppbv}]$ & 50.9 & 52.7 & 62.2 & 54.0 & 55.1 \\
\hline $\mathrm{R}_{\text {Trop }}\left(\mathrm{N}_{2} \mathrm{O}\right)=325 \mathrm{ppbv}$ & & & & & \\
$\mathrm{CO}_{\min }[\mathrm{ppbv}]$ & 35.1 & 35.4 & 54.1 & 38.8 & 35.2 \\
$\mathrm{CO}_{\max }[\mathrm{ppbv}]$ & 44.2 & 39.8 & 68.0 & 46.2 & 47.3 \\
\hline
\end{tabular}

Note that $\mathrm{O}_{3}$ variability (and chemistry) in the lower stratosphere leads to differences in the tropospheric end members of $\mathrm{CO}$ based on the $\mathrm{CO}-\mathrm{O}_{3}$ and $\mathrm{N}_{2} \mathrm{O}-\mathrm{CO}$ correlation. Thus, the formation of ML 1, 2, 4 and 5 can only be caused by the irreversible mixing of stratospheric air masses with different age. In contrast, ML 3 indicates the irreversible mixing of pure tropospheric and stratospheric air masses.

These findings are supported by the meteorological situation and location where the mixing lines were measured. Air masses that form ML 1, 2, 4 and 5 are probed in the centre of a trough far away from the jet stream (see Fig. 2). Since strong convective activity was absent during the flights, fast transport of tropospheric air masses up to $\Theta=400 \mathrm{~K}$ can be ruled out. ML 3 arises, in contrast to the other mixing lines, presumably as a consequence of the irreversible mixing of tropospheric and stratospheric air masses at the jet stream, since this mixing event is measured at the edge of the trough in a region with high wind speed and wind shear (Pan et al., 2006).

\subsection{Results of backward trajectory calculations}

We investigate the origin of ML 1, 2, 4, and 5, which were observed in the trough away from sharp isentropic PV gradients at the tropopause, by analysing 50-day backward trajectories calculated with CLaMS. Variations in potential temperature $\Theta$ along the backward trajectories indicate diabatic processes in the history of the respective air masses. Figure 5 shows measured potential temperature $\Theta$ along TACTS flight 2 (30 August 2012) colour-coded with PV from ECMWF analysis data. Black dots indicate the maximum potential temperature along each individual backward trajectory. These values are typically $20 \mathrm{~K}$ higher than the potential temperature at the position of the aircraft. This is in accordance with descending air masses in the extratropical stratosphere with a rate of approximately $0.5 \mathrm{~K} \mathrm{day}^{-1}$ (Butchart, 2014). Red dots indicate the minimum $\Theta$ for trajectories which show a diabatic ascent prior to the time of measurement. These trajectories are primarily associated with air masses showing large PV values ( $>8 \mathrm{pvu})$ in regions where the mixing lines were encountered. This finding provides an indication that diabatic

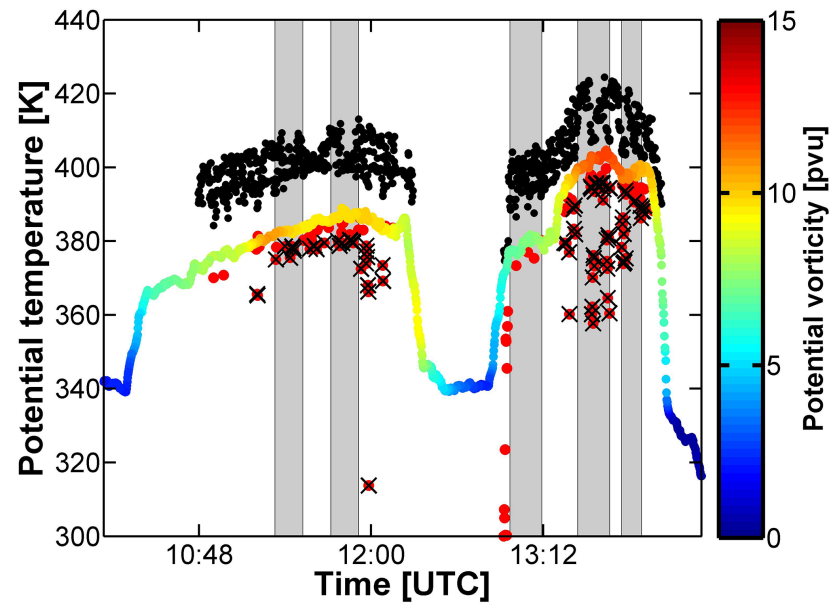

Figure 5. Solid line: time series of potential temperature $\Theta$ measured during the second half of TACTS flight 2 with PV as colour (from ECMWF data). Black dots: maximum potential temperature along 50-day back trajectories for all data points with $\Theta>370$ and $\mathrm{PV}>4 \mathrm{pvu}$ at the measurement location. Red dots further indicate the minimum potential temperature along the trajectories at flight sections where this minimum is below the measured values along the flight track. Red dots with PV > 7.5 pvu and minimum $\Theta$ at least $5 \mathrm{~K}$ smaller than $\Theta$ at the measurement are marked with a black cross (cf. Fig. 6).

upward transport of tropospherically influenced air masses is reflected by the diabatic ascent of the backward trajectories. Figure 6 displays those trajectories which show a potential temperature increase exceeding $5 \mathrm{~K}$. These trajectories indicate an origin in the anticyclone of the Asian summer monsoon and subsequent transport to the measurement region in the Ex-UTLS above $\Theta=400 \mathrm{~K}$. The position of the respective trajectories for -50 days $<t_{\text {Tra }}<-30$ days in Fig. 7 shows that a large fraction of the air masses is located within the Asian monsoon anticyclone for $t_{\text {Tra }}<-30$ days. The lowest potential temperatures along the trajectories (bluish colours) appear within the Asian monsoon region. As shown in Fig. 8 the trajectories spend a significant amount of time in the region, which is affected by the Asian monsoon 


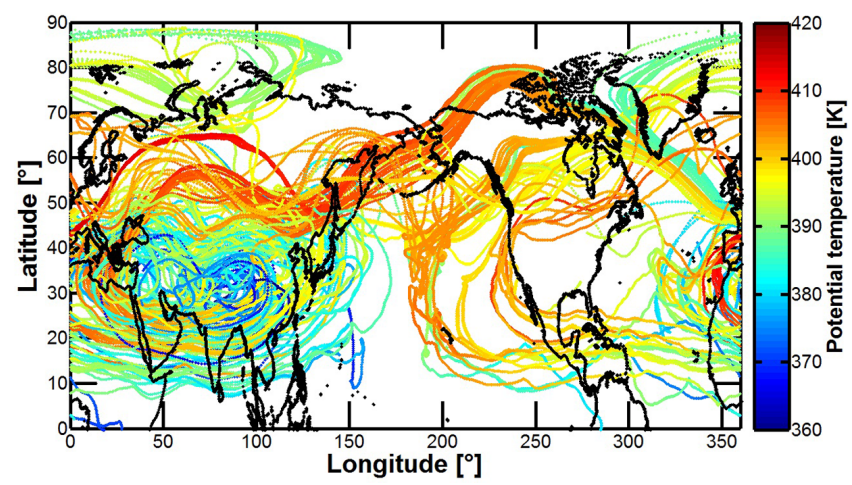

Figure 6. Fifty-day backward trajectories for flight sections where $\Theta>370 \mathrm{~K}, \mathrm{PV}>7.5 \mathrm{pvu}$. To select trajectories which experienced a diabatic ascent to the flight level, we only show trajectories with a minimum potential temperature which is at least $5 \mathrm{~K}$ below $\Theta$ at the measurement location (cf. Fig. 5). Colour: potential temperature along the backward trajectories based on ERA-Interim reanalysis data.

anticyclone. The location of the anticyclone shows large variability within the 2 months prior to the measurements (see Supplement) extending from 20 to $45^{\circ} \mathrm{N}$ during some periods. The longest residence time of trajectories (Fig. 8) is, however, found in those regions which can be associated with the core region of the Asian monsoon anticyclone (Bergman et al., 2013; Garny and Randel, 2016).

The backward trajectory calculation suggests that the diabatic ascent within the Asian monsoon transports tropospheric air masses up to altitudes between 16 and $18 \mathrm{~km}$. Figure 9 shows that this process is accompanied by PV values rising above 5 pvu and $\Theta$ larger than $400 \mathrm{~K}$. These air masses are subsequently transported at $t \approx-30$ days to the extratropics were they mix with aged stratospheric air masses (as measured).

The calculation of 50-day back trajectories cannot provide unambiguous evidence that the transport of air masses from the Asian monsoon into the Ex-UTLS causes the occurrence of mixing lines on the $\mathrm{CO}-\mathrm{O}_{3}$ correlation. CLaMS calculates the vertical motion using diabatic heating rates from ERAInterim, which tend to have a relatively small vertical dispersion in the stratosphere compared to kinematic scenarios (Ploeger et al., 2010). Notably, Vogel et al. (2014) show that 40-day back trajectories, calculated with the same setup of CLaMS as used in this study, agree with trace gas measurements during TACTS flight 6 .

Trace gas measurements of TACTS flight 2 and 50-day back trajectories are consistent, since $\mathrm{CO}-\mathrm{O}_{3}$ mixing lines indicate mixing at $\Theta>380 \mathrm{~K}$. End member analysis shows that recent mixing at the tropopause cannot explain these mixing lines. The mixed air masses have instead experienced a significant $\mathrm{CO}$ degradation in the stratosphere. CLaMS trajectory calculations confirm this conclusion, since a transport time of $t \approx 30$ days from the Asian monsoon region into the

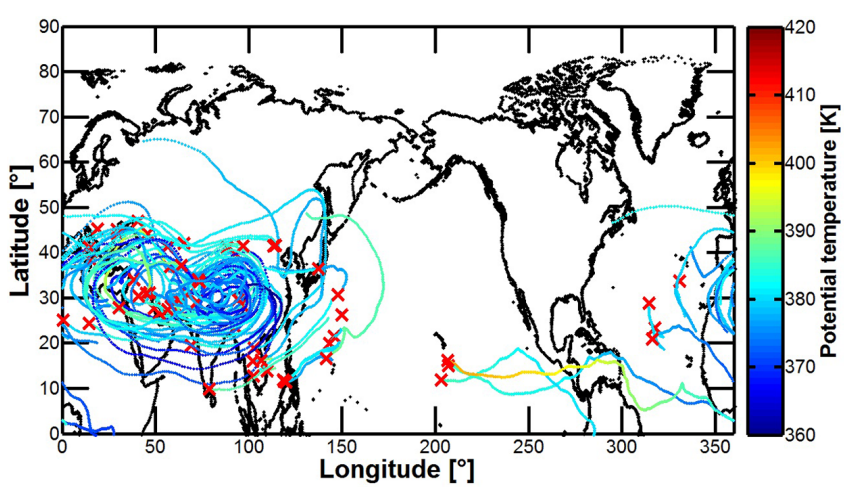

Figure 7. Pathway of the trajectory ensemble as shown in Fig. 6 with $\mathrm{PV}_{\mathrm{Tra}}<5$ pvu. Red crosses mark the location of the trajectories where PV values exceed 5 pvu.

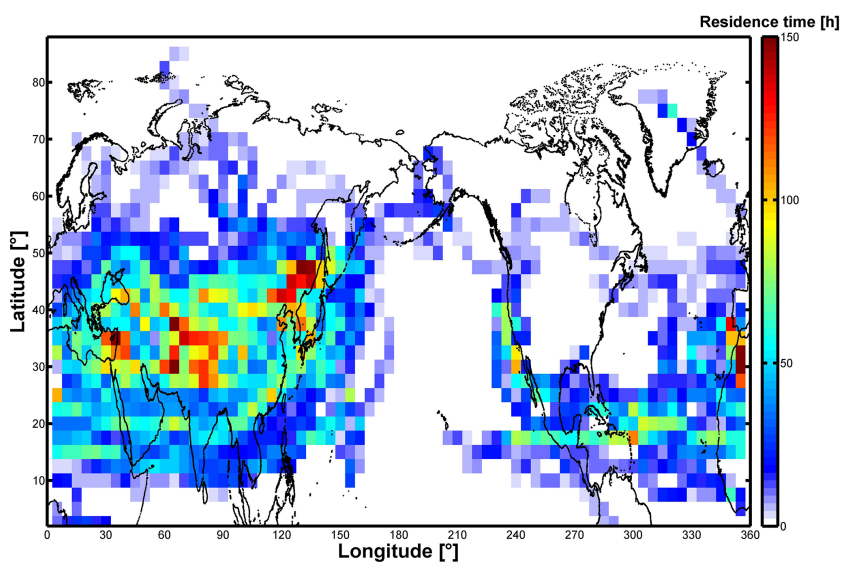

Figure 8. Residence time in hours of the trajectory ensemble as shown in Fig. 6 for -50 days $<t_{\text {Tra }}<-30$ days $\left(2.5^{\circ}\right.$ latitude and $5^{\circ}$ longitude bins). Note the long residence time in the ascending region as indicated in Fig. 7.

Ex-UTLS is indicated by the backward trajectories. A significant contribution from the TTL for this region for TACTS flight 2 cannot be identified based on the trajectory calculations. Thus, it is concluded that the Asian monsoon affects the trace gas composition of the Ex-UTLS for $\Theta>380 \mathrm{~K}$ during TACTS flight 2.

\section{Diagnosis of monsoon transport in the extratropical lower stratosphere}

The effect of the Asian monsoon on the trace gas composition of the Ex-UTLS is investigated by comparing the changes in $\mathrm{N}_{2} \mathrm{O}, \mathrm{CO}$ and $\mathrm{O}_{3}$ from the early measurement phase (28 August-5 September) to the later TACTS flights (23-26 September). The tracer distribution for each period is calculated in bins of equivalent latitude and potential temperature. Figure 10 shows the data coverage for each period. Figure 11 shows the mean distributions for $\mathrm{N}_{2} \mathrm{O}, \mathrm{CO}$ and $\mathrm{O}_{3}$ 

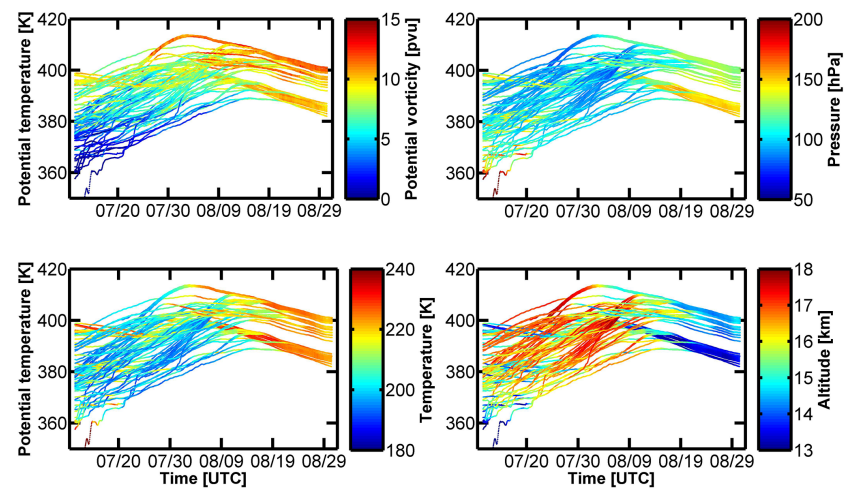

Figure 9. Potential temperature versus time along the trajectory ensemble as shown in Fig. 6. The colour indicates the PV (top left), pressure (top right), temperature (bottom left), and altitude (bottom right) based on ERA-Interim reanalysis data.

in the early and later period and their differences. Also given is the location of the thermal and dynamical tropopause for each period as well as isolines of $\mathrm{PV}=6$ and 8 pvu.

Comparing the tracer distribution of the two phases reveals a slight increase in tropospheric tracers in the stratosphere beyond PV $>8$ pvu. This region is clearly above the ExTL, which extends to $\Delta \Theta=30 \mathrm{~K}$ above the local tropopause (Hoor et al., 2004, 2010). Above the ExTL with $\Delta \Theta>30 \mathrm{~K}$ (relative to the tropopause) an increase in $\mathrm{N}_{2} \mathrm{O}$ is observed. $\mathrm{O}_{3}$ exhibits lower values for the same region during the final phase of the measurements. Both tracers indicate an increasing impact of tropospheric air masses in the extratropical stratosphere above the ExTL. In the tropopause region below 8 pvu the tracer signature is less clear: the distributions of both $\mathrm{CO}$ and $\mathrm{N}_{2} \mathrm{O}$ indicate a slight decrease closer to the tropopause, but with large variability, which is even more pronounced in ozone. To further investigate whether transport from the Asian monsoon anticyclone is responsible for this increase in tropospheric tracers above the ExTL, we analysed CLaMS trajectories for the whole TACTS period. Figure 12 shows the percentage of 50-day backward trajectories originating in the Asian monsoon region (criteria: $25^{\circ} \mathrm{N}<$ TRA-latitude $<40^{\circ} \mathrm{N}, 40^{\circ} \mathrm{E}<$ TRAlongitude $<110^{\circ} \mathrm{E}$ and TRA- $\Theta>360 \mathrm{~K}$ at $t=-30$ days) using the same coordinate system as Fig. 11. These thresholds were chosen according to the mean location of the geopotential anomaly of the anticyclone, shown in Fig. 13, which shows the mean location of the geopotential anomaly relative to the mean geopotential height during JJA in the monsoon area according to Bergman et al. (2013). The darkblue line indicates the monsoon location according to the threshold from Bergman et al. (2013) at $100 \mathrm{hPa}$ (light blue for $200 \mathrm{hPa}$ ). The red contour marks the zero line for anomaly using the mean geopotential height from summer 2012 as the threshold to calculate the anomaly. The difference in the monsoon contribution according to the trajectories in Fig. 12
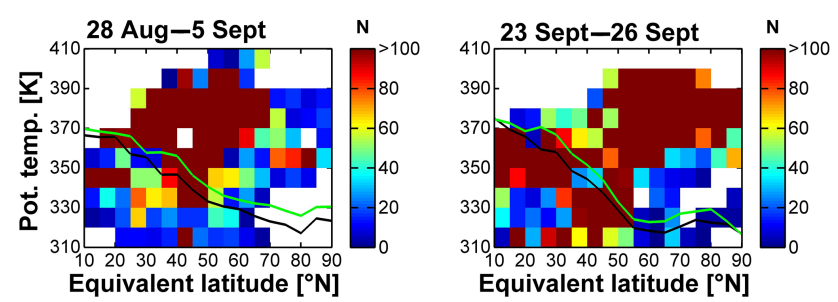

Figure 10. Data coverage (number of data points $\mathrm{N}$ in each bin) of TACTS 2012 in potential temperature $\Theta$ and equivalent latitude $\phi_{\text {eq }}$ coordinates. Left: data coverage of the initial phase of TACTS from 28 August to 5 September. Right: data coverage of the final phase of TACTS from 23 to 26 September. The black and green lines denote the location of the dynamical ( $\mathrm{PV}=2 \mathrm{pvu}$ ) and thermal tropopause, respectively (WMO, 1957).

also shows a bimodal pattern similar to the tracer observations. Trajectories originating from the Asian monsoon region affecting the ExTL are predominantly found for the initial phase of TACTS. In the lower stratosphere above the ExTL, roughly coinciding with the 8 pvu contour, trajectories indicating air masses from the Asian monsoon region are mainly found for the second phase of TACTS. The mean residence time (not shown) of these trajectories within the Asian monsoon anticyclone shows no significant difference for both regions and time periods. The trajectories provide evidence that the measured increased tropospheric influence in the extratropical lower stratosphere above the ExTL arises due to air masses from the Asian monsoon region. A decreased fraction of air masses originating from the Asian monsoon for the later measurements within ExTL indicate, in accordance with lower $\mathrm{CO}$ and $\mathrm{N}_{2} \mathrm{O}$ mixing ratios, a stronger transport barrier between the tropical troposphere and extratropical stratosphere. These results clearly indicate that the Asian monsoon has impacted the extratropical stratosphere above the ExTL during TACTS 2012.

To further analyse the tracer evolution in the LS and the ExTL, we analysed the frequency distributions of the tracers in the stratosphere for $\mathrm{PV}$ values exceeding $\mathrm{PV}=8 \mathrm{pvu}$ (Fig. 14). This relatively high PV value accounts for the fact that the PV at the high tropopause in the subtropics is at 5 pvu (Kunz et al., 2011). It further marks the transition from the ExTL, which is characterised by rapid transport from the local tropopause to the stratosphere (Hoor et al., 2010). For the ExTL we analysed the PV range from 3 to $8 \mathrm{pvu}$ (Fig. 15). The frequency distribution of selected tracers was subdivided into the different phases of TACTS. As indicated in Fig. 14 ( $\mathrm{PV}>8 \mathrm{pvu}$ ), during the early phase (reddish colours) $\mathrm{N}_{2} \mathrm{O}, \mathrm{CO}$ and $\mathrm{SF}_{6}$ are significantly lower than in the late phase. This clearly indicates an increase in tropospheric tracers accompanied by a decreasing age of air as indicated by the increase in $\mathrm{SF}_{6}$. Ozone shows a slight decrease over time with large variability. Water vapour and total water $\left(\mathrm{CH}_{4}+2 \times \mathrm{H}_{2} \mathrm{O}\right)$ also show an increase over time. This 

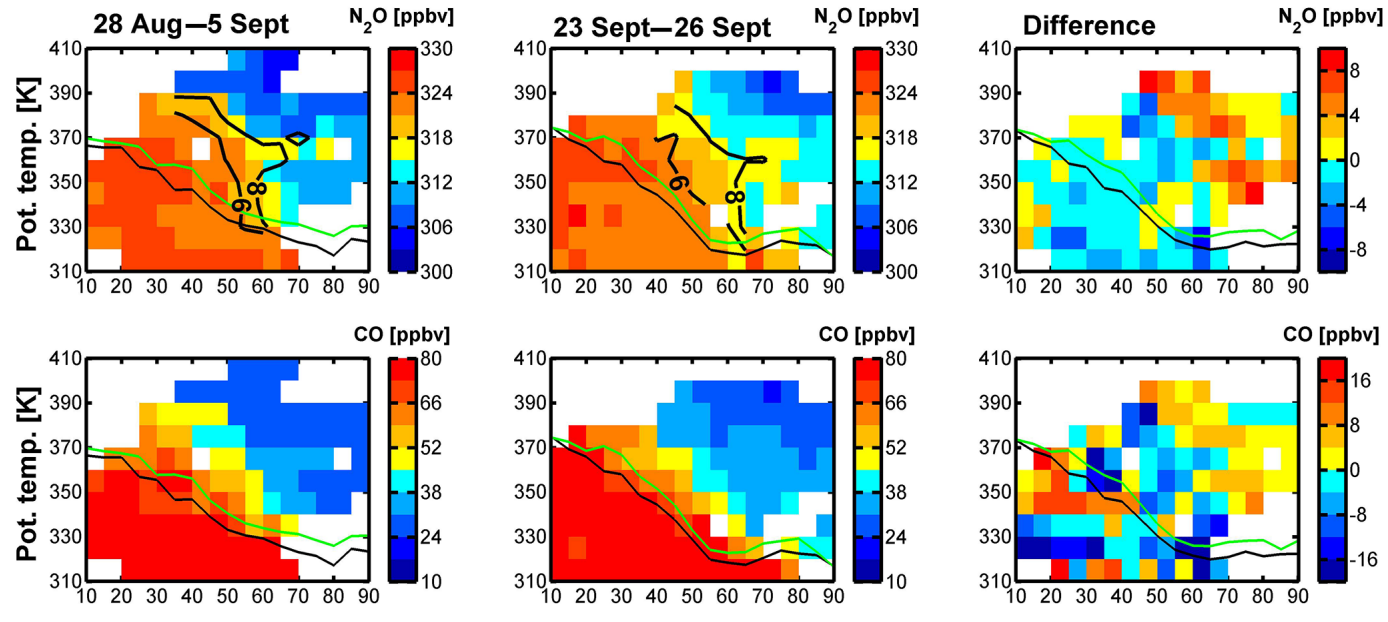

$\mathrm{O}_{3}[\mathrm{ppbv}]$

$\mathrm{O}_{3}[\mathrm{ppbv}]$

$\mathrm{O}_{3}[\mathrm{ppbv}]$
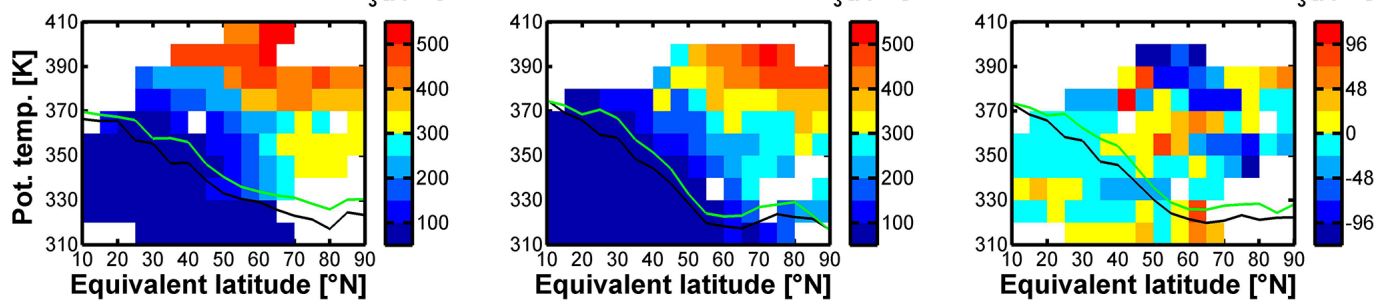

Figure 11. $\mathrm{N}_{2} \mathrm{O}, \mathrm{CO}$, and $\mathrm{O}_{3}$ distributions in potential temperature $\Theta$ and equivalent latitude $\phi_{\text {eq }}$ coordinates for the TACTS 2012 campaign. Left: distributions for the initial phase of TACTS from 28 August to 5 September. Centre: distributions for the final phase of TACTS from 23 to 26 September. Right: changes in the trace gas distributions during the TACTS 2012 campaign (final minus initial phase). The black and green lines denote the location of the dynamical ( $P V=2$ pvu) and thermal tropopause (WMO, 1957), respectively. The thick black line in the upper array denotes the 6 and 8 pvu isolines calculated from ECMWF data along the flight paths.
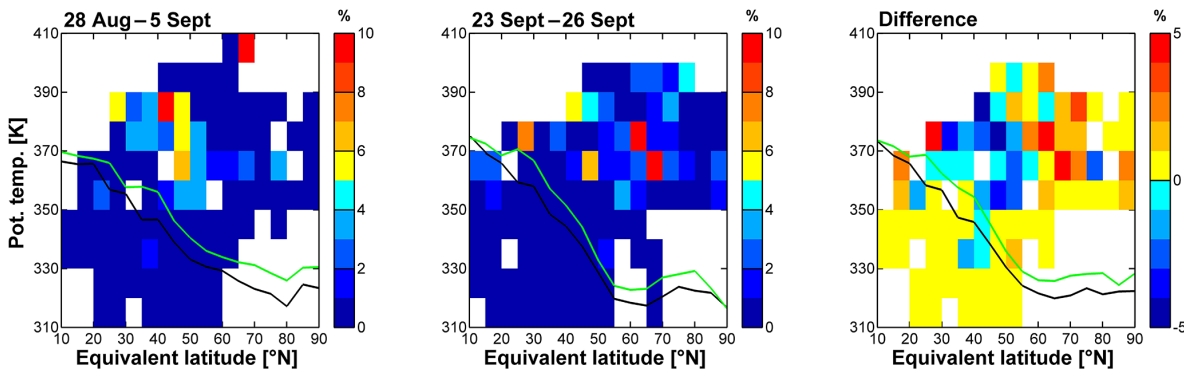

Figure 12. Fraction of data points for which 50-day backward trajectories calculated with CLaMS-TRAJ indicate an origin in the Asian summer monsoon anticyclone (criteria: $25^{\circ} \mathrm{N}<$ TRA-latitude $<40^{\circ} \mathrm{N}, 40^{\circ} \mathrm{E}<$ TRA-longitude $<110^{\circ} \mathrm{E}$ and TRA- $\Theta>360 \mathrm{~K}$ for $t=-30$ days).

finding also indicates a stronger contribution from the monsoon region which tends to moisten the mid-latitude lower stratosphere during this time of the year (Randel and Jensen, 2013).

Histograms for trace gas mixing ratios in the ExTL in Fig. 15, here defined as the region between 3 and 8 pvu (Hoor et al., 2010), are less consistent. The frequency distributions of $\mathrm{CO}$ and $\mathrm{N}_{2} \mathrm{O}$ show large variability and rather a stagnant or even decreasing tropospheric contribution. Lower CO mixing ratios in the tropopause region indicate that the observed increase in tropospheric tracers in the lower stratosphere down to $\Theta=350 \mathrm{~K}$ (Fig. 11) is not due to isentropic transport across the subtropical jet. If rapid transport of tropospheric air into the stratosphere were responsible for the increased tropospheric signatures above the ExTL, CO would also have increased in the ExTL. Therefore, the transport of relatively young stratospheric air masses with a large tropospheric air mass fraction at $\Theta>380 \mathrm{~K}$ is responsible for larger mixing ratios of tropospheric $\left(\mathrm{N}_{2} \mathrm{O}\right.$ and $\left.\mathrm{CO}\right)$ and lower mixing ratios of stratospheric tracers $\left(\mathrm{O}_{3}\right)$ above the ExTL. At mid- and 
high latitudes these air masses subsequently descend to lower potential temperatures. These results are in accordance with previous studies regarding the Ex-UTLS region (Hoor et al., 2002, 2004, 2010; Bönisch et al., 2009; Hegglin et al., 2006). It is likely that strengthening of the jet stream in September weakens transport of tropospheric air masses into the ExTL (Haynes and Shuckburgh, 2000; Berthet et al., 2007; Sawa et al., 2008), which subsequently leads to lower CO mixing ratios at the final stage of the TACTS measurements. Independent of this transport pathway, the transport of Asian monsoon influenced air masses (as measured during TACTS flight 2) by the shallow branch of the BDC above $\Theta=400 \mathrm{~K}$ leads to a stronger tropospheric influence above the ExTL.

\section{Discussion and Summary}

The tracer measurements over Europe during TACTS 2012 and the backward trajectory analysis provide a coherent picture, indicating a distinct influence of the Asian summer monsoon on the mid-latitude UTLS. The combination of tools provide a consistent picture, which can be summarised as follows.

1. Based on in situ trace gas measurements, irreversible mixing of different air masses in the Ex-UTLS above $\Theta=380 \mathrm{~K}$ was observed during TACTS 2012.

2. The tropospheric end member approximation shows that the observed irreversible mixing occurred rather between stratospheric air masses with different tropospheric contributions than between undiluted tropospheric and stratospheric air masses.

3. Backward trajectories indicate that the younger of the mixed stratospheric air masses were affected by the Asian monsoon circulation.

1. An effect of the Asian monsoon on the LS over Europe is also evident from the overall trace gas distributions measured during TACTS 2012. These show that the Ex-UTLS composition over Europe has significantly changed within 20-30 days during the campaign. Above the ExTL a stronger impact of tropospherically influenced air masses in late September compared to late August 2012 is indicated by larger $\mathrm{CO}$ and $\mathrm{N}_{2} \mathrm{O}$ and lower $\mathrm{O}_{3}$ mixing ratios. Within the ExTL, a weakening of the tropospheric influence is indicated by decreasing CO.

2. Backward trajectories indicate that the Asian monsoon strongly affected the LS predominantly during the late phase of TACTS 2012. Within the ExTL such trajectories are preferably found during the initial phase of the campaign.
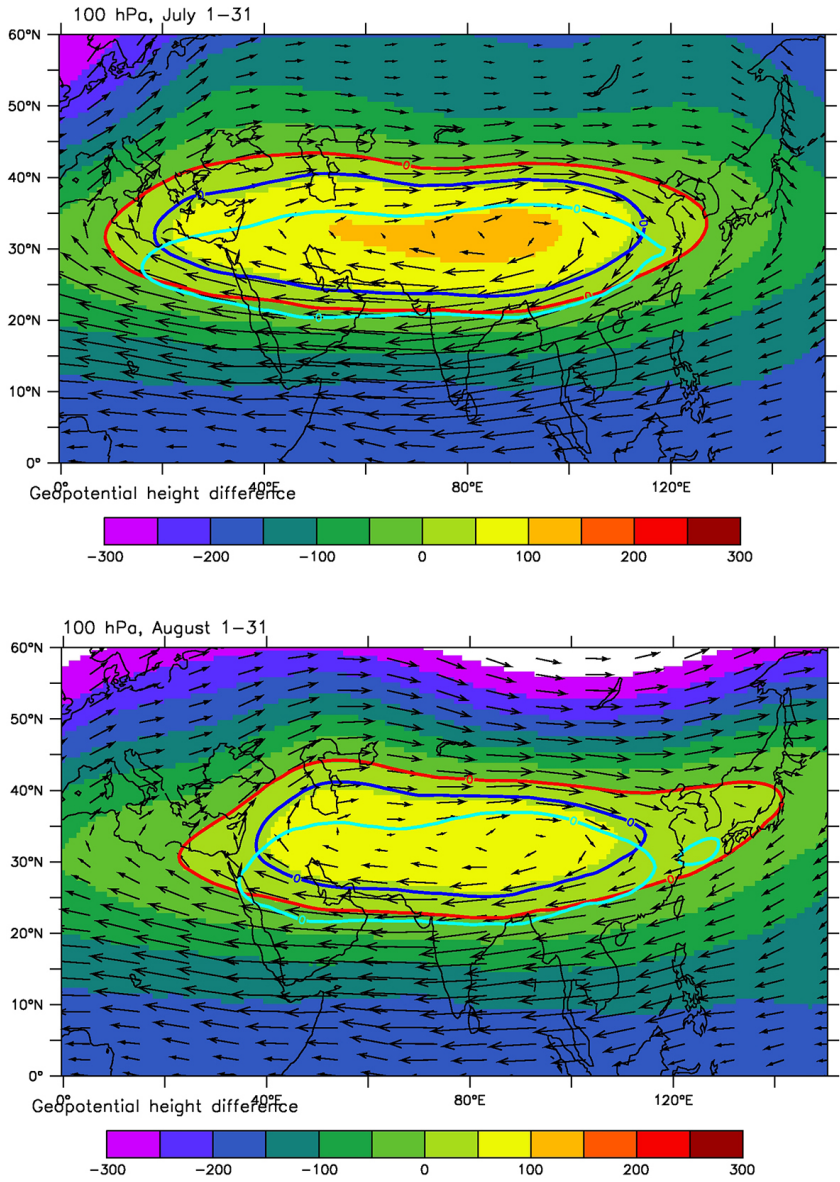

Figure 13. Geopotential height relative to the climatological mean for JJA following the method of Bergman et al. (2013). The darkblue line indicates the monsoon location according to the threshold from Bergman et al. (2013) at $100 \mathrm{hPa}$ (light blue for $200 \mathrm{hPa}$ ). The red contour marks the zero line using the mean geopotential height from summer 2012 as the threshold to calculate the anomaly.

Our study suggests that the transport of air masses from the Asian monsoon region into the extratropical stratosphere is a contributor to the change in the Ex-UTLS chemical composition during summer and autumn of the Northern Hemisphere (Hoor et al., 2005; Hegglin and Shepherd, 2007; Bönisch et al., 2009). In situ data of $\mathrm{N}_{2} \mathrm{O}, \mathrm{CO}$ and $\mathrm{O}_{3}$ indicate a significant increase in the tropospheric impact in the extratropical lower stratosphere above the ExTL within a few weeks. This finding indicates that water vapour (Ploeger et al., 2013; Randel and Jensen, 2013) as well as other atmospheric constituents (and pollutants), which were not measured, is potentially affected by transport from the Asian monsoon circulation.

A case study based on in situ data shows that air masses originating from the Asian monsoon are quasi-isentropically transported above $\Theta=380 \mathrm{~K}$ into the Ex-UTLS during summer and autumn 2012. This confirms the results of model simulations and satellite data of Ploeger et al. (2013), which 

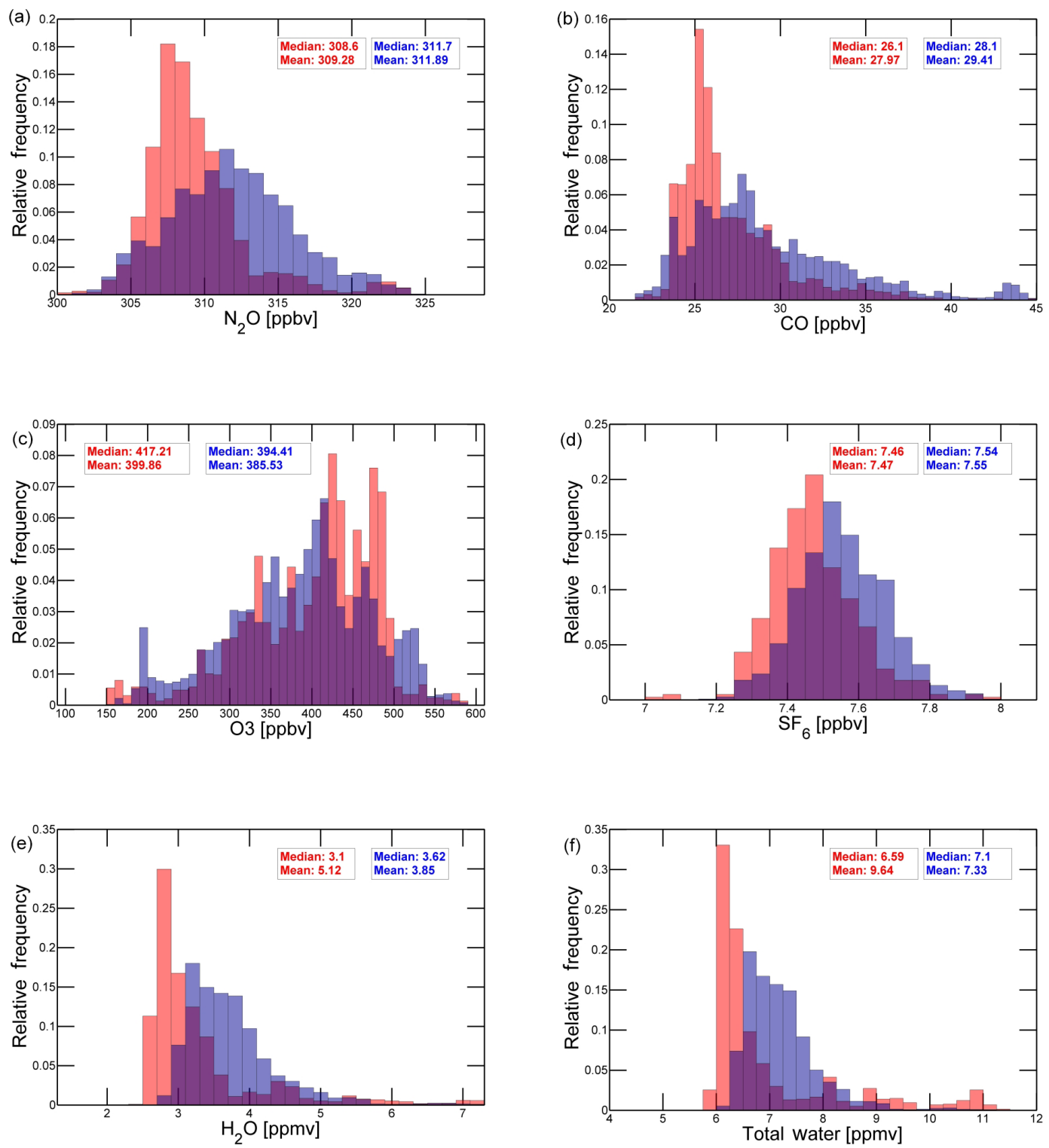

Figure 14. Relative frequency of (a) $\mathrm{N}_{2} \mathrm{O}$, (b) $\mathrm{CO}$, (c) $\mathrm{O}_{3}$, (d) $\mathrm{SF}_{6}$, (e) $\mathrm{H}_{2} \mathrm{O}$, and (f) total water $\left(\mathrm{CH}_{4}+2 \times \mathrm{H}_{2} \mathrm{O}\right)$, for data points with $\mathrm{PV}>8 \mathrm{pvu}$. Reddish colours denote the histogram for the initial phase from the 28 August to 5 September, while bluish colours denote those for the final phase of TACTS from 23 to 26 September. Purple areas display the overlap of both histograms.

show enhanced water vapour transport from the tropics (and the Asian monsoon region) into the extratropics during boreal summer above $\Theta=380 \mathrm{~K}$. A relatively large effective diffusivity between the tropics and extratropics during summer and autumn for potential temperatures ranging from 380 to $450 \mathrm{~K}$ is also in accordance with our results (Haynes and Shuckburgh, 2000). Further, Haynes and Shuckburgh (2000) calculate a decreasing effective diffusivity from summer to autumn for $\Theta$ between 350 and $370 \mathrm{~K}(13-15 \mathrm{~km})$, which indicates an increasing transport barrier from the early to the late monsoon season at the jet location. The measurement of lower CO within the ExTL during the later phase of TACTS compared to the initial phase agrees with a stronger transport barrier for mixing across the tropopause below $\Theta=380 \mathrm{~K}$. In accordance with this, Ploeger et al. (2015) diagnose on the basis of the PV gradient a strong transport barrier that separates the anticyclone from its surrounding and inhibits isentropic transport and mixing between $\Theta=360$ and $380 \mathrm{~K}$. Our measurements also support the hypothesis of an efficient transport of tropospheric trace gases (e.g. CO) to the upper Asian monsoon troposphere (Bergman et al., 2013). From the upper tropospheric monsoon region a fraction of these air masses is efficiently transported and mixed into the lower stratosphere of mid- and high latitudes at potential tempera- 

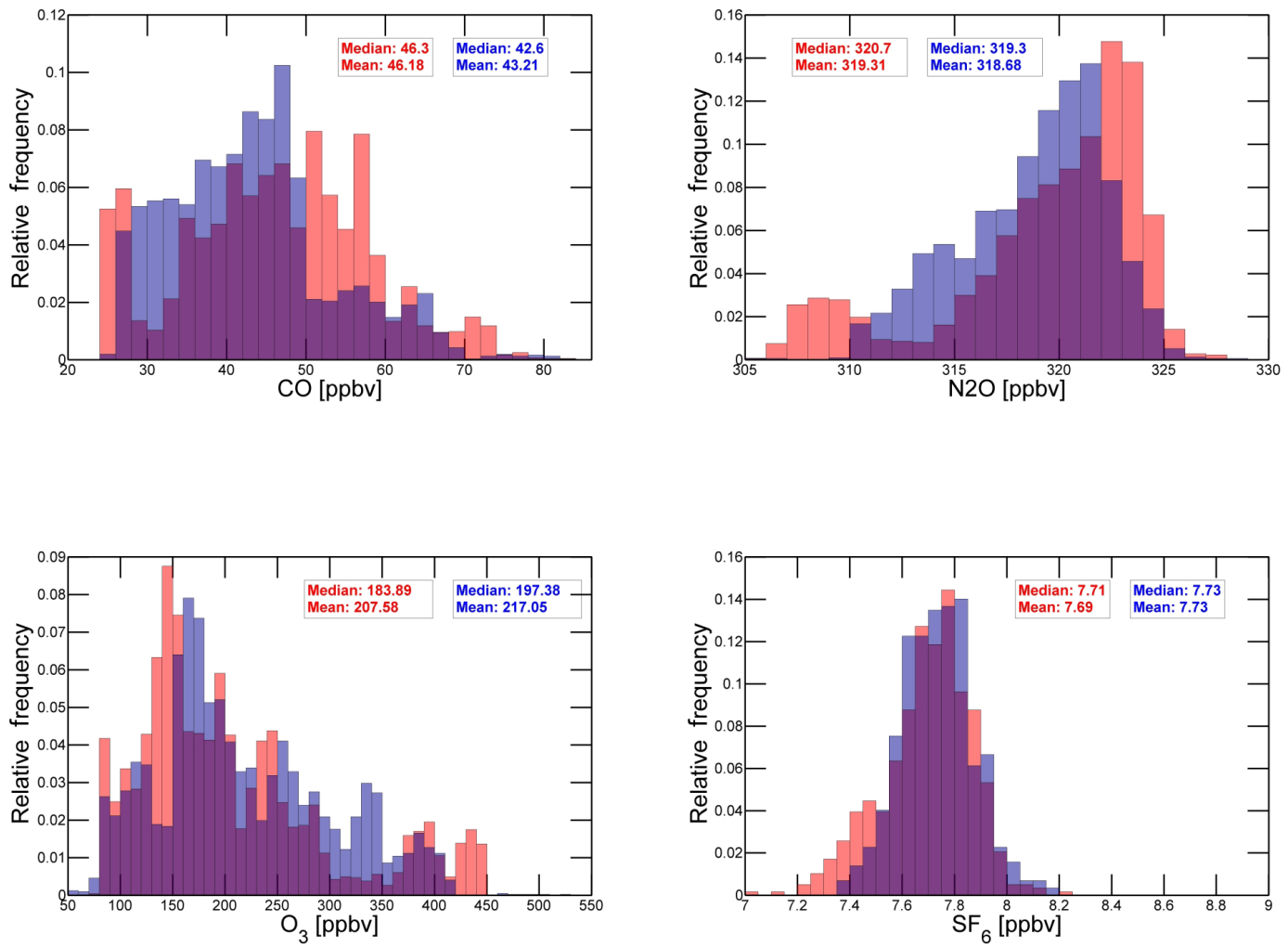

Figure 15. Same as Fig. 14 (without $\mathrm{H}_{2} \mathrm{O}$ and total water histograms) for data with PV ranging from 3 to 8 pvu.

tures $\Theta>380 \mathrm{~K}$ (Berthet et al., 2007). Thus, our data show that the Asian summer monsoon affects the overall tracer distribution over Europe with increasing efficiency from August to September 2012.

\section{Conclusions}

In situ measurements of $\mathrm{CO}, \mathrm{O}_{3}$ and $\mathrm{N}_{2} \mathrm{O}$ during TACTS 2012 show a significant change in the trace gas composition over the course of 4 weeks in the Ex-UTLS up to $\Theta=410 \mathrm{~K}$. From August to late September 2012 a distinct increase in $\mathrm{N}_{2} \mathrm{O}$ and $\mathrm{CO}$ (and decreasing $\mathrm{O}_{3}$ ) indicate a stronger tropospheric contribution above the ExTL up to $\Theta=410 \mathrm{~K}$. Decreasing CO mixing ratios in the ExTL below $\Theta=370 \mathrm{~K}$ indicate a weakening of the quasi-isentropic transport across the tropopause at the jet stream into the lowermost stratosphere (Pan et al., 2006). Therefore, it is concluded that the observed increase in the tropospheric fraction above the ExTL is not caused by quasi-isentropic cross tropopause transport at the jet stream. We conclude that the observed increase in tropospheric influence in the ExTL above $370 \mathrm{~K}$ originates in a region with a high tropopause. Fifty-day backward trajectories from CLaMS-TRAJ indicate that the Asian summer monsoon has affected the composition of the ExUTLS over Europe during TACTS 2012. In agreement with the tracer observations, the CLaMS trajectories show an in- creasing contribution of air originating in the Asian summer monsoon to the extratropical lower stratosphere during September 2012. Notably, the trajectories exhibit a mean residence time of $t>200 \mathrm{~h}$ in the Asian monsoon anticyclone in the last 50 days before the measurements. Within the monsoon circulation the trajectories slowly rise up to $\Theta>400 \mathrm{~K}$. As shown in a case study in Sect. 3, the monsoon-affected air masses are transported to the measurement region within 30 days. For the global tracer distribution increasing $\mathrm{SF}_{6}$ values for the late phase of the measurements consistently indicate an increasing contribution of younger air, in agreement with the analysis of the backward trajectories. Further, the simultaneously observed increase in (total) water vapour for the same air masses is in accordance with the horizontal tape recorder of $\mathrm{H}_{2} \mathrm{O}$ at $\Theta=390 \mathrm{~K}$ caused by the Asian monsoon (Randel and Jensen, 2013). Thus, our results indicate that the Asian summer monsoon affected the chemical composition of the Ex-UTLS over Europe during TACTS in 2012. We therefore conclude that the Asian summer monsoon in general might be an important contributor to the flushing of the boreal extratropical lower stratosphere from summer to autumn (Hegglin and Shepherd, 2007) when the tropospheric signature is at a maximum (Hoor et al., 2005; Bönisch et al., 2009). 


\section{Data availability}

HALO TACTS and ESMVal data are archived in a public password-protected data archive (https://halo-db.pa.op. dlr.de). In situ data used in this publication can be further accessed by contacting the principal investigator of the TRIHOP instrument: Peter Hoor at the University of Mainz (hoor@uni-mainz.de). Meteorological data (ERA-Interim) are available from the European Centre for Medium-Range Weather Forecasts (ECMWF).

\section{The Supplement related to this article is available online at doi:10.5194/acp-16-10573-2016-supplement.}

Acknowledgements. Thanks go to Michael Sprenger and Heini Wernli for the calculation of tropopause information and providing ECMWF data. Further we thank Horst Fischer for helpful discussions and comments on the manuscript and for providing the TRIHOP instrument. Also, the technical support before and during the TACTS campaign by Uwe Parchatka and Rainer Königstedt is acknowledged. In particular, we thank the flight department of the DLR, especially the pilots, for execution of the flights. We also thank the University of Mainz for financial support of the experiments. Flight planning for the TACTS/ESMVal campaign was assisted with CLaMS model forecasts, supported by the German Research Foundation (DFG) through project LASSO (HALO-SPP 1294/GR3786).

Edited by: F. Fierli

Reviewed by: three anonymous referees

\section{References}

Assonov, S., Brenninkmeijer, C., Schuck, T., and Umezawa, T.: $\mathrm{N}_{2} \mathrm{O}$ as a tracer of mixing stratospheric and tropospheric air based on CARIBIC data with applications for $\mathrm{CO}_{2}$, Atmos. Environ., 79, 769-779, doi:10.1016/j.atmosenv.2013.07.035, 2013.

Baker, A. K., Schuck, T. J., Slemr, F., van Velthoven, P., Zahn, A., and Brenninkmeijer, C. A. M.: Characterization of nonmethane hydrocarbons in Asian summer monsoon outflow observed by the CARIBIC aircraft, Atmos. Chem. Phys., 11, 503518, doi:10.5194/acp-11-503-2011, 2011.

Bergman, J. W., Fierli, F., Jensen, E. J., Honomichl, S., and Pan, L. L.: Boundary layer sources for the Asian anticyclone: Regional contributions to a vertical conduit, J. Geophys. Res. Atmos., 118, 2560-2575, doi:10.1002/jgrd.50142, 2013.

Berthet, G., Esler, J. G., and Haynes, P. H.: A Lagrangian perspective of the tropopause and the ventilation of the lowermost stratosphere, J. Geophys. Res., 112, D18102, doi:10.1029/2006JD008295, 2007.

Birner, T. and Bönisch, H.: Residual circulation trajectories and transit times into the extratropical lowermost stratosphere, Atmos. Chem. Phys., 11, 817-827, doi:10.5194/acp-11-817-2011, 2011.
Bönisch, H., Engel, A., Curtius, J., Birner, Th., and Hoor, P.: Quantifying transport into the lowermost stratosphere using simultaneous in-situ measurements of SF6 and $\mathrm{CO}_{2}$, Atmos. Chem. Phys., 9, 5905-5919, doi:10.5194/acp-9-5905-2009, 2009.

Bourassa, A. E., Robock, A., Randel, W. J., Deshler, T., Rieger, L. A., Lloyd, N. D., Llewellyn, E. J., and Degenstein, D. A.: Large volcanic aerosol load in the stratosphere linked to Asian monsoon transport, Science, 337, 78-81, doi:10.1126/science.1219371, 2012.

Brewer, A. W.: Evidence for a world circulation provided by the measurements of helium and water vapour distribution in the stratosphere, Q. J. Roy. Meteor. Soc., 75, 351-363, doi:10.1002/qj.49707532603, 1949.

Butchart, N.: The Brewer-Dobson circulation, Rev. Geophys., 52, 157-184, doi:10.1002/2013RG000448, 2014.

Chen, B., Xu, X. D., Yang, S., and Zhao, T. L.: Climatological perspectives of air transport from atmospheric boundary layer to tropopause layer over Asian monsoon regions during boreal summer inferred from Lagrangian approach, Atmos. Chem. Phys., 12, 5827-5839, doi:10.5194/acp-12-5827-2012, 2012.

Dee, D. P., Uppala, S. M., Simmons, A. J., Berrisford, P., Poli, P., Kobayashi, S., Andrae, U., Balmaseda, M. A., Balsamo, G., Bauer, P., Bechtold, P., Beljaars, A. C. M., van de Berg, L., Bidlot, J., Bormann, N., Delsol, C., Dragani, R., Fuentes, M., Geer, A. J., Haimberger, L., Healy, S. B., Hersbach, H., Hólm, E. V., Isaksen, L., Kållberg, P., Köhler, M., Matricardi, M., McNally, A. P., Monge-Sanz, B. M., Morcrette, J.-J., Park, B.-K., Peubey, C., de Rosnay, P., Tavolato, C., Thépaut, J.-N., and Vitart, F.: The ERA-Interim reanalysis: configuration and performance of the data assimilation system, Q. J. Roy. Meteor. Soc., 137, 553-597, doi:10.1002/qj.828, 2011.

Dobson, G. M. B.: Origin and Distribution of the Polyatomic Molecules in the Atmosphere, P. Roy. Soc. Lond. A. Mat., 236, 187-193, 1956.

Fadnavis, S., Semeniuk, K., Pozzoli, L., Schultz, M. G., Ghude, S. D., Das, S., and Kakatkar, R.: Transport of aerosols into the UTLS and their impact on the Asian monsoon region as seen in a global model simulation, Atmos. Chem. Phys., 13, 8771-8786, doi:10.5194/acp-13-8771-2013, 2013.

Fadnavis, S., Schultz, M. G., Semeniuk, K., Mahajan, A. S., Pozzoli, L., Sonbawne, S., Ghude, S. D., Kiefer, M., and Eckert, E.: Trends in peroxyacetyl nitrate (PAN) in the upper troposphere and lower stratosphere over southern Asia during the summer monsoon season: regional impacts, Atmos. Chem. Phys., 14, 12725-12743, doi:10.5194/acp-14-12725-2014, 2014.

Fadnavis, S., Semeniuk, K., Schultz, M. G., Kiefer, M., Mahajan, A., Pozzoli, L., and Sonbawane, S.: Transport pathways of peroxyacetyl nitrate in the upper troposphere and lower stratosphere from different monsoon systems during the summer monsoon season, Atmos. Chem. Phys., 15, 11477-11499, doi:10.5194/acp-15-11477-2015, 2015.

Fischer, H., Wienhold, F. G., Hoor, P., Bujok, O., Schiller, C., Siegmund, P., Ambaum, M., Scheeren, H. A., and Lelieveld, J.: Tracer correlations in the northern high latitude lowermost stratosphere: Influence of cross-tropopause mass exchange, Geophys. Res. Lett., 27, 97-100, doi:10.1029/1999GL010879, 2000.

Flocke, F., Herman, R. L., Salawitch, R. J., Atlas, E., Webster, C. R., Schauffler, S. M., Lueb, R. A., May, R. D., Moyer, E. J., Rosenlof, K. H., Scott, D. C., Blake, D. R., and 
Bui, T. P.: An examination of chemistry and transport processes in the tropical lower stratosphere using observations of long-lived and short-lived compounds obtained during STRAT and POLARIS, J. Geophys. Res. Atmos., 104, 26625-26642, doi:10.1029/1999JD900504, 1999.

Forster, P. M. D. F. and Shine, K. P.: Assessing the climate impact of trends in stratospheric water vapor, Geophys. Res. Lett., 29, 10-14, doi:10.1029/2001GL013909, 2002.

Fueglistaler, S., Dessler, A. E., Dunkerton, T. J., Folkins, I., Fu, Q., and Mote, P. W.: Tropical tropopause layer, Rev. Geophys., 47, RG1004, doi:10.1029/2008RG000267, 2009.

Garny, H. and Randel, W. J.: Dynamic variability of the Asian monsoon anticyclone observed in potential vorticity and correlations with tracer distributions, J. Geophys. Res. Atmos., 118, 13413421433, doi:10.1002/2013JD020908, 2013.

Garny, H. and Randel, W. J.: Transport pathways from the Asian monsoon anticyclone to the stratosphere, Atmos. Chem. Phys., 16, 2703-2718, doi:10.5194/acp-16-2703-2016, 2016.

Gettelman, A., Hoor, P., Pan, L. L., Randel, W. J., Hegglin, M. I., and Birner, T.: The extratropical upper troposphere and lower stratosphere, Rev. Geophys., 49, RG3003, doi:10.1029/2011RG000355, 2011.

Glatthor, N., von Clarmann, T., Stiller, G. P., Funke, B., Koukouli, M. E., Fischer, H., Grabowski, U., Höpfner, M., Kellmann, S., and Linden, A.: Large-scale upper tropospheric pollution observed by MIPAS $\mathrm{HCN}$ and $\mathrm{C}_{2} \mathrm{H}_{6}$ global distributions, Atmos. Chem. Phys., 9, 9619-9634, doi:10.5194/acp-9-9619-2009, 2009.

Haynes, P. and Shuckburgh, E.: Effective diffusivity as a diagnostic of atmospheric transport: 2. Troposphere and lower stratosphere, J. Geophys. Res. Atmos., 105, 22795-22810, doi:10.1029/2000JD900092, 2000.

Hegglin, M. I. and Shepherd, T. G.: $\mathrm{O}_{3}-\mathrm{N}_{2} \mathrm{O}$ correlations from the Atmospheric Chemistry Experiment: Revisiting a diagnostic of transport and chemistry in the stratosphere, J. Geophys. Res., 112, D19301, doi:10.1029/2006JD008281, 2007.

Hegglin, M. I. and Shepherd, T. G.: Large climate-induced changes in ultraviolet index and stratosphere-to-troposphere ozone flux, Nat. Geosci., 2, 687-691, doi:10.1038/ngeo604, 2009.

Hegglin, M. I., Brunner, D., Peter, T., Hoor, P., Fischer, H., Staehelin, J., Krebsbach, M., Schiller, C., Parchatka, U., and Weers, U.: Measurements of $\mathrm{NO}, \mathrm{NO}_{y}, \mathrm{~N}_{2} \mathrm{O}$, and $\mathrm{O}_{3}$ during SPURT: implications for transport and chemistry in the lowermost stratosphere, Atmos. Chem. Phys., 6, 1331-1350, doi:10.5194/acp-61331-2006, 2006.

Herman, R. L., Webster, C. R., May, R. D., Scott, D. C., Hu, H., Moyer, E. J., Wennberg, P. O., Hanisco, T. F., Lanzendorf, E. J., Salawitch, R. J., Yung, Y. L., Margitan, J. J., and Bui, T. P.: Measurements of CO in the upper troposphere and lower stratosphere, Chem. Glob. Chang. Sci., 1, 173-183, doi:10.1016/S1465-9972(99)00008-2, 1999.

Highwood, E. J. and Hoskins, B. J.: The tropical tropopause, Q. J. Roy. Meteor. Soc., 124, 1579-1604, doi:10.1002/qj.49712454911, 1998.

Hintsa, E. J., Boering, K. A., Weinstock, E. M., Anderson, J. G., Gary, B. L., Pfister, L., Daube, B. C., Wofsy, S. C., Loewenstein, M., Podolske, J. R., Margitan, J. J., and Bui, T. P.: Troposphereto-stratosphere transport in the lowermost stratosphere from measurements of $\mathrm{H}_{2} \mathrm{O}, \mathrm{CO}_{2}, \mathrm{~N}_{2} \mathrm{O}$ and $\mathrm{O}_{3}$, Geophys. Res. Lett., 25, 2655-2658, doi:10.1029/98GL01797, 1998.

Holton, J. R., Haynes, P. H., McIntyre, M. E., Douglass, A. R., Rood, R. B., and Pfister, L.: Stratosphere-troposphere exchange, Rev. Geophys., 33, 403-439, doi:10.1029/95RG02097, 1995.

Hoor, P., Fischer, H., Lange, L., Lelieveld, J., and Brunner, D.: Seasonal variations of a mixing layer in the lowermost stratosphere as identified by the $\mathrm{CO}-\mathrm{O}_{3}$ correlation from in situ measurements, J. Geophys. Res. Atmos., 107, ACL 1-1-ACL 1-11, doi:10.1029/2000JD000289, 2002.

Hoor, P., Gurk, C., Brunner, D., Hegglin, M. I., Wernli, H., and Fischer, H.: Seasonality and extent of extratropical TST derived from in-situ CO measurements during SPURT, Atmos. Chem. Phys., 4, 1427-1442, doi:10.5194/acp-4-1427-2004, 2004.

Hoor, P., Fischer, H., and Lelieveld, J.: Tropical and extratropical tropospheric air in the lowermost stratosphere over Europe: A CO-based budget, Geophys. Res. Lett., 32, L07802, doi:10.1029/2004GL022018, 2005.

Hoor, P., Wernli, H., Hegglin, M. I., and Bönisch, H.: Transport timescales and tracer properties in the extratropical UTLS, Atmos. Chem. Phys., 10, 7929-7944, doi:10.5194/acp-10-79292010, 2010.

Hoskins, B. J., McIntyre, M. E., and Robertson, A. W.: On the use and significance of isentropic potential vorticity maps, Q. J. Roy. Meteor. Soc., 111, 877-946, doi:10.1002/qj.49711147002, 1985.

Hsu, C. J. and Plumb, R. A.: Nonaxisymmetric Thermally Driven Circulations and Upper-Tropospheric Monsoon Dynamics, J. Atmos. Sci., 57, 1255-1276, 2000.

James, R. and Legras, B.: Mixing processes and exchanges in the tropical and the subtropical UT/LS, Atmos. Chem. Phys., 9, 2538, doi:10.5194/acp-9-25-2009, 2009.

Jurkat, T., Voigt, C., Kaufmann, S., Zahn, A., Sprenger, M., Hoor, P., Bozem, H., Müller, S., Dörnbrack, A., Schlager, H., Bönisch, H., and Engel, A.: A quantitative analysis of stratospheric $\mathrm{HCl}, \mathrm{HNO}_{3}$, and $\mathrm{O}_{3}$ in the tropopause region near the subtropical jet, Geophys. Res. Lett., 41, 3315-3321, doi:10.1002/2013GL059159, 2014.

Konopka, P. and Pan, L. L.: On the mixing-driven formation of the Extratropical Transition Layer (ExTL), J. Geophys. Res. Atmos., 117, D18301, doi:10.1029/2012JD017876, 2012.

Konopka, P., Grooß, J.-U., Günther, G., Ploeger, F., Pommrich, R., Müller, R., and Livesey, N.: Annual cycle of ozone at and above the tropical tropopause: observations versus simulations with the Chemical Lagrangian Model of the Stratosphere (CLaMS), Atmos. Chem. Phys., 10, 121-132, doi:10.5194/acp-10-121-2010, 2010.

Kumar, A., Wu, S., Weise, M. F., Honrath, R., Owen, R. C., Helmig, D., Kramer, L., Val Martin, M., and Li, Q.: Free-troposphere ozone and carbon monoxide over the North Atlantic for 20012011, Atmos. Chem. Phys., 13, 12537-12547, doi:10.5194/acp13-12537-2013, 2013.

Kunz, A., Konopka, P., Müller, R., and Pan, L. L.: Dynamical tropopause based on isentropic potential vorticity gradients, J. Geophys. Res., 116, D01110, doi:10.1029/2010JD014343, 2011.

McKenna, D. S., Grooß, J.-U., Günther, G., Konopka, P., Müller, R., Carver, G., and Sasano, Y.: A new Chemical Lagrangian Model of the Stratosphere (CLaMS) 2. Formulation of chemistry scheme and initialization, J. Geophys. Res. Atmos., 107, ACH 4-1-ACH 4-14, doi:10.1029/2000JD000113, 2002 a. 
McKenna, D. S., Konopka, P., Grooß, J.-U., Günther, G., Müller, R., Spang, R., Offermann, D., and Orsolini, Y.: A new Chemical Lagrangian Model of the Stratosphere (CLaMS) 1. Formulation of advection and mixing, J. Geophys. Res. Atmos., 107, ACH 15-1-ACH 15-15, doi:10.1029/2000JD000114, 2002 b.

Müller, S., Hoor, P., Berkes, F., Bozem, H., Klingebiel, M., Reutter, P., Smit, H. G. J., Wendisch, M., Spichtinger, P., and Borrmann, S.: In situ detection of stratosphere-troposphere exchange of cirrus particles in the midlatitudes, Geophys. Res. Lett., 42, 949955, doi:10.1002/2014GL062556, 2015.

Palazzi, E., Fierli, F., Cairo, F., Cagnazzo, C., Di Donfrancesco, G., Manzini, E., Ravegnani, F., Schiller, C., D'Amato, F., and Volk, C. M.: Diagnostics of the Tropical Tropopause Layer from in-situ observations and CCM data, Atmos. Chem. Phys., 9, 9349-9367, doi:10.5194/acp-9-9349-2009, 2009.

Pan, L. L.: Definitions and sharpness of the extratropical tropopause: A trace gas perspective, J. Geophys. Res., 109, D23103, doi:10.1029/2004JD004982, 2004.

Pan, L. L., Konopka, P., and Browell, E. V.: Observations and model simulations of mixing near the extratropical tropopause, J. Geophys. Res., 111, D05106, doi:10.1029/2005JD006480, 2006.

Park, M., Randel, W. J., Kinnison, D. E., Garcia, R. R., and Choi, W.: Seasonal variation of methane, water vapor, and nitrogen oxides near the tropopause: Satellite observations and model simulations, J. Geophys. Res. Atmos., 109, D03302, doi:10.1029/2003JD003706, 2004.

Park, M., Randel, W. J., Gettelman, A., Massie, S. T., and Jiang, J. H.: Transport above the Asian summer monsoon anticyclone inferred from Aura Microwave Limb Sounder tracers, J. Geophys. Res., 112, D16309, doi:10.1029/2006JD008294, 2007.

Park, M., Randel, W. J., Emmons, L. K., Bernath, P. F., Walker, K. A., and Boone, C. D.: Chemical isolation in the Asian monsoon anticyclone observed in Atmospheric Chemistry Experiment (ACE-FTS) data, Atmos. Chem. Phys., 8, 757-764, doi:10.5194/acp-8-757-2008, 2008.

Park, M., Randel, W. J., Emmons, L. K., and Livesey, N. J.: Transport pathways of carbon monoxide in the Asian summer monsoon diagnosed from Model of Ozone and Related Tracers (MOZART), J. Geophys. Res. Atmos., 114, D08303, doi:10.1029/2008JD010621, 2009.

Ploeger, F., Konopka, P., Günther, G., Grooß, J.-U., and Müller, R.: Impact of the vertical velocity scheme on modeling transport in the tropical tropopause layer, J. Geophys. Res., 115, D03301, doi:10.1029/2009JD012023, 2010.

Ploeger, F., Günther, G., Konopka, P., Fueglistaler, S., Müller, R., Hoppe, C., Kunz, A., Spang, R., Grooß, J.-U., and Riese, M.: Horizontal water vapor transport in the lower stratosphere from subtropics to high latitudes during boreal summer, J. Geophys. Res. Atmos., 118, 8111-8127, doi:10.1002/jgrd.50636, 2013.

Ploeger, F., Gottschling, C., Griessbach, S., Grooß, J.-U., Guenther, G., Konopka, P., Müller, R., Riese, M., Stroh, F., Tao, M., Ungermann, J., Vogel, B., and von Hobe, M.: A potential vorticitybased determination of the transport barrier in the Asian summer monsoon anticyclone, Atmos. Chem. Phys., 15, 13145-13159, doi:10.5194/acp-15-13145-2015, 2015.

Pommrich, R., Müller, R., Grooß, J.-U., Konopka, P., Ploeger, F., Vogel, B., Tao, M., Hoppe, C. M., Günther, G., Spelten, N., Hoffmann, L., Pumphrey, H.-C., Viciani, S., D’Amato, F., Volk, C. M., Hoor, P., Schlager, H., and Riese, M.: Tropical troposphere to stratosphere transport of carbon monoxide and long-lived trace species in the Chemical Lagrangian Model of the Stratosphere (CLaMS), Geosci. Model Dev., 7, 2895-2916, doi:10.5194/gmd7-2895-2014, 2014.

Popovic, J. M. and Plumb, R. A.: Eddy Shedding from the UpperTropospheric Asian Monsoon Anticyclone, J. Atmos. Sci., 58, 93-104, 2001.

Press, W., Teukolsky, S., Vetterling, W., Flannery, B., and Yudin, V.: Numerical Recipes: The Art of Scientific Computing, Cambridge Univ. Press Cambridge, New York, 2nd Edn., 1992.

Randel, W. J. and Jensen, E. J.: Physical processes in the tropical tropopause layer and their roles in a changing climate, Nat. Geosci, 6, 169-176, doi:10.1038/ngeo1733, 2013.

Randel, W. J. and Park, M.: Deep convective influence on the Asian summer monsoon anticyclone and associated tracer variability observed with Atmospheric Infrared Sounder (AIRS), J. Geophys. Res. Atmos., 111, D12314, doi:10.1029/2005JD006490, 2006.

Randel, W. J., Seidel, D. J., and Pan, L. L.: Observational characteristics of double tropopauses, J. Geophys. Res., 112, D07309, doi:10.1029/2006JD007904, 2007.

Randel, W. J., Park, M., Emmons, L., Kinnison, D., Bernath, P., Walker, K. A., Boone, C., and Pumphrey, H.: Asian monsoon transport of pollution to the stratosphere, Science, 328, 611-3, doi:10.1126/science.1182274, 2010.

Richter, A., Burrows, J. P., Nusz, H., Granier, C., and Niemeier, U.: Increase in tropospheric nitrogen dioxide over China observed from space, Nature, 437, 129-132, 2005.

Riese, M., Ploeger, F., Rap, A., Vogel, B., Konopka, P., Dameris, M., and Forster, P.: Impact of uncertainties in atmospheric mixing on simulated UTLS composition and related radiative effects, J. Geophys. Res., 117, D16305, doi:10.1029/2012JD017751, 2012.

Riese, M., Oelhaf, H., Preusse, P., Blank, J., Ern, M., Friedl-Vallon, F., Fischer, H., Guggenmoser, T., Höpfner, M., Hoor, P., Kaufmann, M., Orphal, J., Plöger, F., Spang, R., Suminska-Ebersoldt, O., Ungermann, J., Vogel, B., and Woiwode, W.: Gimballed Limb Observer for Radiance Imaging of the Atmosphere (GLORIA) scientific objectives, Atmos. Meas. Tech., 7, 1915-1928, doi:10.5194/amt-7-1915-2014, 2014.

Rosenlof, K. H., Tuck, A. F., Kelly, K. K., Russell, J. M., and McCormick, M. P.: Hemispheric asymmetries in water vapor and inferences about transport in the lower stratosphere, J. Geophys. Res. Atmos., 102, 13213-13234, doi:10.1029/97JD00873, 1997.

Sawa, Y., Machida, T., and Matsueda, H.: Seasonal variations of $\mathrm{CO} 2$ near the tropopause observed by commercial aircraft, J. Geophys. Res. Atmos., 113, D23301, doi:10.1029/2008JD010568, 2008.

Schiller, C. L., Bozem, H., Gurk, C., Parchatka, U., Königstedt, R., Harris, G. W., Lelieveld, J., and Fischer, H.: Applications of quantum cascade lasers for sensitive trace gas measurements of $\mathrm{CO}, \mathrm{CH}_{4}, \mathrm{~N}_{2} \mathrm{O}$ and $\mathrm{HCHO}$, Appl. Phys. B, 92, 419-430, doi:10.1007/s00340-008-3125-0, 2008.

Schuck, T. J., Brenninkmeijer, C. A. M., Baker, A. K., Slemr, F., von Velthoven, P. F. J., and Zahn, A.: Greenhouse gas relationships in the Indian summer monsoon plume measured by the CARIBIC passenger aircraft, Atmos. Chem. Phys., 10, 3965 3984, doi:10.5194/acp-10-3965-2010, 2010.

Spackman, J. R., Weinstock, E. M., Anderson, J. G., Hurst, D. F., Jost, H.-J., and Schauffler, S. M.: Aircraft observa- 
tions of rapid meridional transport from the tropical tropopause layer into the lowermost stratosphere: Implications for midlatitude ozone, J. Geophys. Res. Atmos., 112, D12308, doi:10.1029/2006JD007618, 2007.

Strahan, S. E.: Climatologies of lower stratospheric $\mathrm{NO}_{y}$ and $\mathrm{O}_{3}$ and correlations with $\mathrm{N}_{2} \mathrm{O}$ based on in situ observations, J. Geophys. Res., 104, 30463, doi:10.1029/1999JD900775, 1999.

Thouret, V., Cammas, J.-P., Sauvage, B., Athier, G., Zbinden, R., Nédélec, P., Simon, P., and Karcher, F.: Tropopause referenced ozone climatology and inter-annual variability (1994-2003) from the MOZAIC programme, Atmos. Chem. Phys., 6, 1033-1051, doi:10.5194/acp-6-1033-2006, 2006.

Vogel, B., Günther, G., Müller, R., Grooß, J.-U., Hoor, P., Krämer, M., Müller, S., Zahn, A., and Riese, M.: Fast transport from Southeast Asia boundary layer sources to northern Europe: rapid uplift in typhoons and eastward eddy shedding of the Asian monsoon anticyclone, Atmos. Chem. Phys., 14, 12745-12762, doi:10.5194/acp-14-12745-2014, 2014.

Volk, C. M., Elkins, J. W., Fahey, D. W., Salawitch, R. J., Dutton, G. S., Gilligan, J. M., Proffitt, M. H., Loewenstein, M., Podolske, J. R., Minschwaner, K., Margitan, J. J., and Chan, K. R.: Quantifying Transport Between the Tropical and Mid-Latitude Lower Stratosphere, Science, 272, 1763-1768, 1996.
WMO: Meteorology, A three-dimensional science, WMO Bull., 134-138, 1957.

Zahn, A. and Brenninkmeijer, C. A. M.: New Directions: A Chemical Tropopause Defined, Atmos. Environ., 37, 439-440, 2003.

Zahn, A., Brenninkmeijer, C. A. M., Maiss, M., Scharffe, D. H., Crutzen, P. J., Hermann, M., Heintzenberg, J., Wiedensohler, A., Güsten, H., Heinrich, G., Fischer, H., Cuijpers, J. W. M., and van Velthoven, P. F. J.: Identification of extratropical two-way troposphere-stratosphere mixing based on CARIBIC measurements of $\mathrm{O}_{3}, \mathrm{CO}$, and ultrafine particles, J. Geophys. Res. Atmos., 105, 1527-1535, doi:10.1029/1999JD900759, 2000.

Zahn, A., Weppner, J., Widmann, H., Schlote-Holubek, K., Burger, B., Kühner, T., and Franke, H.: A fast and precise chemiluminescence ozone detector for eddy flux and airborne application, Atmos. Meas. Tech., 5, 363-375, doi:10.5194/amt-5-363-2012, 2012. 